\title{
Indoor Air Pollution, Related Human Diseases, and Recent Trends in the Control and Improvement of Indoor Air Quality
}

\author{
Vinh Van Tran ${ }^{1,2}$, Duckshin Park ${ }^{3, *(1)}$ and Young-Chul Lee ${ }^{1, *(\mathbb{D}}$ \\ 1 Department of BioNano Technology, Gachon University, 1342 Seongnam-Daero, Sujeong-Gu, Seongnam-Si, \\ Gyeonggi-do 13120, Korea; vanvinhkhmtk30@gmail.com \\ 2 Institute of Research and Development, Duy Tan University, Da Nang 550000, Vietnam \\ 3 Korea Railroad Research Institute (KRRI), 176 Cheoldobakmulkwan-ro, \\ Uiwang-si 16105, Gyeonggi-do, Korea \\ * Correspondence: dspark@krri.re.kr (D.P.); dreamdbs@gachon.ac.kr (Y.-C.L.)
}

Received: 26 March 2020; Accepted: 22 April 2020; Published: 23 April 2020

\begin{abstract}
Indoor air pollution (IAP) is a serious threat to human health, causing millions of deaths each year. A plethora of pollutants can result in IAP; therefore, it is very important to identify their main sources and concentrations and to devise strategies for the control and enhancement of indoor air quality (IAQ). Herein, we provide a critical review and evaluation of the major sources of major pollutant emissions, their health effects, and issues related to IAP-based illnesses, including sick building syndrome (SBS) and building-related illness (BRI). In addition, the strategies and approaches for control and reduction of pollutant concentrations are pointed out, and the recent trends in efforts to resolve and improve IAQ, with their respective advantages and potentials, are summarized. It is predicted that the development of novel materials for sensors, IAQ-monitoring systems, and smart homes is a promising strategy for control and enhancement of IAQ in the future.
\end{abstract}

Keywords: indoor air quality; indoor pollution; smart home; human diseases

\section{Introduction}

Indoor environment conditions contribute greatly to human wellbeing, as most people spend around $90 \%$ of their time indoors, mainly at home or in the workplace [1]. According to the World Health Organization (WHO), indoor air pollution (IAP) is responsible for the deaths of 3.8 million people annually [2]. IAP can be generated inside homes or buildings through occupants' activities, such as cooking, smoking, use of electronic machines, use of consumer products, or emission from building materials. Harmful pollutants inside buildings include carbon monoxide (CO), volatile organic compounds (VOCs), particulate matter (PM), aerosol, biological pollutants, and others [3]. Therefore, over the past decade, research on air quality control has begun to shift from outdoor to indoor environments, as reflects lifestyle changes linked to increased levels of urbanization [4]. It was indicated that decreased IAQ can negatively affect human health by causing building-associated illness [5]. Both short- and long-term IAP exposure can cause a wide range of diseases [6]. Therefore, the development of monitoring systems has a vital role to play in IAQ control.

IAP normally is a complex mixture of particulate and various gaseous components. IAP compositions differ significantly depending on sources, emission rates, and ventilation conditions [7]. For effective control of IAQ, therefore, it is necessary to determine the sources of air pollution. Moreover, the development of monitoring systems for the measurement of indoor pollutant concentrations as well as key strategies for control and enhancement of IAQ are considered essential. In this paper, we provide a comprehensive overview of the major IAP sources and IAQ-control strategies; 
we emphasize the sources, characteristics, and health effects of each IAP; we identify and discuss health issues and building-associated illnesses related to an IAQ decrease; and finally, we present the recent and trending strategies for the control and reduction of pollutant concentrations and better IAQ. It is expected that promising strategies for monitoring and control of IAQ in the future will include novel materials-based sensors, smart monitoring systems, and smart homes.

\section{Indoor Air Quality (IAQ) and Indoor Air Pollution (IAP)}

According to the EPA's definition, IAQ is the air quality within and around buildings and structures, especially as it relates to the health and comfort of building occupants [8]. IAP, meanwhile, refers to the existence of pollutants, such as volatile organic compounds (VOCs), particulate matter (PM), inorganic compounds, physical chemicals, and biological factors, all of which are at high concentrations in the indoor air of non-industrial buildings, and all of which can have negative impacts on the human body. In order to protect people from such pollutants, IAQ has emerged and been developed as a research field [9]. The main parameters for evaluation of IAQ include pollutant concentrations, thermal conditions (temperature, airflow, relative humidity), light, and noise. Thermal conditions are crucial aspects of IAQ, for two basic reasons [10,11]: (i) Several problems related to poor IAQ can be solved simply by adjusting the relative humidity or temperature, and (ii) building materials in high-temperature buildings can be highly released.

It has been indicated that IAQ in residential areas or buildings is significantly affected by three primary factors [12,13]: (i) Outdoor air quality, (ii) human activity in buildings, and (iii) building and construction materials, equipment, and furniture. It is known that outdoor contaminant concentrations and building airtightness have a great influence on IAQ, due to the possibility of transportation of contaminants from outdoors to indoors [14]. As outdoor pollutants' concentrations increase, they are transported from outdoors to the indoor environment via ventilation. Hence, the correlation of outdoor air pollution with IAQ highly depends on the ventilation rate additionally to the lifetimes and mixing ratios of such pollutants [15]. Human daily activities generally cause IAP by the discharge of waste gases, tobacco smoke, pesticides, solvents, cleaning agents, particulates, dust, mold, fibers, and allergens [16]. Humans also create favorable conditions for the development of millions of mold, fungus, pollen, spores, bacteria, viruses, and insects, such as dust mites and roaches. Combustion sources and cooking activates contribute to carbon dioxide $\left(\mathrm{CO}_{2}\right)$, sulfur dioxide $\left(\mathrm{SO}_{2}\right), \mathrm{CO}$, nitrogen dioxide $\left(\mathrm{NO}_{2}\right)$, and particulate matter $(\mathrm{PM})$ emissions into indoor air environments [17,18]. In addition, equipment, such as computers, photocopy machines, printers, and other office machines, emit ozone (O3) and volatile compounds. Common building materials, such as poly(vinyl chloride) PVC floor covering, parquet, linoleum, rubber carpet, adhesive, lacquer, paint, sealant, and particle board, can shed toxic compounds (i.e., alkanes, aromatic compounds, 2-ethylhexanol, acetophenone, alkylated aromatic compounds, styrene, toluene, glycols, glycolesters, texanol, ketones, esters, siloxane, and formaldehyde) [10].

Importantly, the design and operation of ventilation systems also have a significant influence on IAQ. Due to superseding the stale indoor air by the fresh outdoor air, ventilation creates suitable IAQ and a healthy indoor environment. There are several benefits for the operation of ventilation in a building [19], including: (i) Providing oxygen and fresh air for human respiration; (ii) diluting indoor air pollutants to reach the short-term exposure limits of harmful contaminants as well as odors and vapors; (iii) using outdoor air with a low aerosol concentration to control aerosols inside buildings; (iv) controlling internal humidity; and (v) creating proper air distribution and promoting healthy and comfortable environment. Ventilation systems can be classified into two types [20], including: (i) Mechanical ventilation systems that use mechanical equipment, such as fans or blowers; and (ii) natural ventilation systems, which are the exchange processes between indoor air and out indoor without using mechanical equipment. Although natural ventilation systems may be well adopted by the occupants, they are insufficient in some buildings or climates. These days, mechanical ventilation systems have been commonly used in buildings, which significantly increases energy 
consumption. Thus, hybrid ventilation systems are designed to take advantage of both mechanical and natural ventilation systems, in order to decrease energy consumption and increase the use of sustainable technologies [21]. In hybrid ventilation systems, the shortcomings of natural ventilation will be compensated by mechanical components [22]. In summary, in heating, ventilation, and air conditioning (HVAC) systems of buildings, ventilation plays a key role in creating suitable IAQ, but it is also responsible for energy consumption. Therefore, improving ventilation systems in buildings is the key issue not only for enhancing energy efficiency but also for providing better IAQ to the occupants and minimizing the possibility of health problems as a consequence [21].

\section{Main Pollutants in Indoor Air Environment}

Numerous indoor air pollutants have been recognized to have harmful impacts on IAQ and human health [23]. The main indoor air pollutants include NOx, volatile and semi-volatile organic compounds (VOCs), $\mathrm{SO}_{2}, \mathrm{O}_{3}, \mathrm{CO}, \mathrm{PM}$, radon, toxic metals, and microorganisms. The sources and health effects of some common pollutants are listed in Table 1 . Some of them can be present in both indoor and outdoor environments, while others originate from the outdoor environment. Generally, indoor air pollutants are able to be classified into organic, inorganic, biological, or radioactive [24].

\subsection{Particulate Matters}

PM is defined as carbonaceous particles in association with adsorbed organic chemicals and reactive metals. PM's main components are sulfates, nitrates, endotoxin, polycyclic aromatic hydrocarbons, and heavy metals (iron, nickel, copper, zinc, and vanadium) [7]. Depending on the particle size, PM generally is classified into (i) coarse particles, $\mathrm{PM}_{10}$ of diameter $<10 \mu \mathrm{m}$; (ii) fine particles, $\mathrm{PM}_{2.5}$ of diameter $<2.5 \mu \mathrm{m}$; and (iii) ultrafine particles, $\mathrm{PM}_{0.1}$ of diameter $<0.1 \mu \mathrm{m}$. PM is especially concerning, as it is sometimes inhalable, affecting the lungs and heart and causing serious health effects. It has been shown that indoor PM levels often exceed outdoor ones [25]. Indoor PM sources include (i) particles that migrate from the outdoor environment and (ii) particles generated by indoor activities. Cooking, fossil fuel combustion activities, smoking, machine operation, and residential hobbies are the main reasons why $\mathrm{PM}$ is distributed inside of buildings. Compared with $\mathrm{PM}_{10}$ and $\mathrm{PM}_{2.5}, \mathrm{PM}_{0.1}$ created by fossil fuel combustion represents a greater threat to health due to its penetrability into the small airways as well as alveoli $[26,27]$. According to research about the concentration of major indoor pollutants, it has been indicated that cooking and cigarette smoking are the largest sources of indoor air PM, whereas cleaning activities often have a lesser contribution to indoor PM [28]. Smoking is known as a major source of indoor $\mathrm{PM}_{2.5}$, with estimated increases in homes with smokers ranging from 25 to $45 \mu \mathrm{g} / \mathrm{m}^{3}$ and the concentration in winter is greater than in summer [29]. For cooking activity, it was shown that cooking activities enable the emission of millions of particles $\left(\sim 10^{6}\right.$ particles $\left./ \mathrm{cm}^{3}\right)$ through the burning of oil, wood, and food and most of them are ultra-fine particles [30,31]. In addition, these fine particles can distribute not only to the kitchen but also spread to the living room and other areas in the building, thereby causing adverse effects to the occupants' health [31,32]. Meanwhile, other normal human activities, such as walking around and sitting on furniture, are likely to resuspend house dust and contribute to $25 \%$ of the indoor PM concentrations [29]. In summary, it has been found that the source strengths for human activities ranged from 0.03 to $0.5 \mathrm{mg} \cdot \mathrm{min}^{-1}$ for $\mathrm{PM}_{2.5}$ and from 0.1 and 1.4 mg. $\mathrm{min}^{-1}$ for $\mathrm{PM}_{10}$ [33].

\subsection{VOCs}

Volatile organic compounds (VOCs) are recognized as gases containing a variety of chemicals emitted from liquids or solids [34]. Formaldehyde, a colorless gas with an acrid smell and which is released from many building materials, such as particleboard, plywood, and glues, is one of the most widespread VOCs. VOC concentrations in indoor environments are at least 10 times higher than outdoors, regardless of the building location [34,35]. Generally, indoor VOCs are generated from four main sources: (i) Human activities, including cooking, smoking, and the use of cleaning and personal 
care products; (ii) generation from indoor chemical reactions; (iii) penetration of outdoor air through infiltration and ventilation systems; and (iv) originating from building materials [35-39]. The VOCs concentration is able to be affected by air exchange rates, house age and size, building renovations, outdoor VOC levels, and door and window opening [40]. Moreover, it has been demonstrated that about 50 different VOCs are identified during 90-min cooking periods [35]. Because VOCs are organic chemicals that possess a low boiling point $\left(\mathrm{T}_{\mathrm{b}}\right)$ and are easily volatilized even at room temperature, the WHO classified them into four groups: (i) Very volatile organic compounds (VVOCs) with $\mathrm{T}_{\mathrm{b}}$ : 50-100 ${ }^{\circ} \mathrm{C}$; (ii) volatile organic compounds (VOCs) with $100{ }^{\circ} \mathrm{C}<\mathrm{T}_{\mathrm{b}}<240{ }^{\circ} \mathrm{C}$; (iii) semi-volatile inorganic compounds (SVOCs) with $240{ }^{\circ} \mathrm{C}<\mathrm{T}_{\mathrm{b}}<380^{\circ} \mathrm{C}$; and (iv) particulate organic matter (POM) with $\mathrm{T}_{\mathrm{b}}>380^{\circ} \mathrm{C}[41,42]$. Normally, exposure to VOCs released from consumer products is incurred via three main pathways: Inhalation, ingestion, or dermal contact. Most people are not seriously affected by short-term exposure to low concentrations of VOCs, but in cases of long-term exposure, some VOCs are considered to be harmful risks to human health, potentially causing cancer [43]. As for SVOCs, transdermal uptake directly from air has a higher contribution compared with intake via inhalation $[44,45]$.

\section{3. $N O_{X}$}

The two principal nitrogen oxides are nitric oxide (NO) and nitrogen dioxide $\left(\mathrm{NO}_{2}\right)$, both of which are associated with combustion sources, such as cooking stoves and heaters [46]. Ambient concentrations of $\mathrm{NO}$ and $\mathrm{NO}_{2}$ vary widely depending on local sources and sinks. Their average concentration in buildings without combustion activities is half that in the outdoors, but when gas stoves and heaters are used, indoor levels often exceed outdoor levels. Under ambient conditions, NO is rapidly oxidized to form $\mathrm{NO}_{2}$; hence, $\mathrm{NO}_{2}$ is usually considered as a primary pollutant. The reaction of $\mathrm{NO}_{2}$ with water produces nitrous acid (HONO), a strong oxidant and common pollutant of indoor environments [47]. It has been indicated that indoor levels of $\mathrm{NO}_{2}$ are a function of both outdoor and indoor sources; hence, indoor levels can be influenced by high outdoor levels originating from combustion or local traffic sources. It was reported that the distance between buildings and roadways has a significant influence on indoor $\mathrm{NO}_{2}$ levels [48]. Besides, the air exchange between outdoors and indoors also affects $\mathrm{NO}_{2}$ levels in buildings [49]. Additionally, the major indoor sources include smoking and wood-, gas-, oil-, coal-, and kerosene-burning appliances, such as stoves, space, ovens, and water heaters and fireplaces [47].

\subsection{Ozone}

Ozone is a powerful oxidizing agent mainly produced by photochemical reactions of $\mathrm{O}_{2}, \mathrm{NOx}$, and VOCs in the atmosphere. However, it cannot be used to eliminate other indoor chemical pollutants, due to its slow reaction with most airborne pollutants [50,51]. Ozone enables rapid reaction with several indoor pollutants, but the reaction products can irritate humans and damage materials. The main sources of indoor ozone mainly come from the outdoor atmosphere and the operation of electrical devices [52]. The machines commonly emitting indoor ozone gas include photocopiers, disinfecting devices, air-purifying devices, and other office devices [53-56]. The ozone emission mechanisms of these devices can be divided into two categories: Corona discharge and photochemical mechanisms. It has been shown that indoor ozone levels depend on various factors: (i) The outdoor ozone level; (ii) indoor emission rates; (iii) air-exchange rates; (iv) surface-removal rates, and (v) reactions between other chemicals and ozone in the air [50]. Indoor ozone levels generally fluctuate between $20 \%$ and $80 \%$ of the outdoor ozone level according to the air-exchange rate [57]. Humans are exposed to ozone primarily by inhalation, but skin exposure is also a recognized vector [58].

\section{5. $\mathrm{SO}_{2}$}

Sulfur dioxide $\left(\mathrm{SO}_{2}\right)$ is the most common gas among the group of sulfur oxides $\left(\mathrm{SO}_{\mathrm{x}}\right)$ present in the atmosphere. $\mathrm{SO}_{2}$ is primarily produced by the combustion process of fossil fuels, and combines 
with aerosols and PMs to form a complex group of distinct air [59]. Indoor sources of $\mathrm{SO}_{2}$ emissions include vented gas appliances, oil furnaces, tobacco smoke, kerosene heaters, and coal or wood stoves [60]. In addition, outdoor air is also regarded as a main source of indoor $\mathrm{SO}_{2}$ [61]. Indoor $\mathrm{SO}_{2}$ levels are often lower than outdoor levels. $\mathrm{SO}_{2}$ emission indoors is usually small, owing to its reactivation, which can be easily absorbed by indoor surfaces. It is known that the hourly concentration of $\mathrm{SO}_{2}$ in buildings is often below $20 \mathrm{ppb}$ [62]. Human exposure to $\mathrm{SO}_{2}$, which can impair respiratory function, is only via inhalation.

\section{6. $\mathrm{COx}$}

Carbon monoxide (CO) in indoor air is produced mainly by combustion processes, such as cooking or heating. Besides, $\mathrm{CO}$ can also enter into indoor environments through infiltration from outdoor air [63]. The important sources of indoor $\mathrm{CO}$ emissions include unvented kerosene and gas space heaters; leaking chimneys and furnaces; back-drafting from furnaces, gas water heaters, wood stoves, and fireplaces; gas stoves; generators and other gasoline-powered equipment; and tobacco smoke [47]. The average concentration of $\mathrm{CO}$ in a building without any gas stoves is about $0.5-5 \mathrm{ppm}$, while the concentration in areas near gas stoves ranges from 5 to $15 \mathrm{ppm}$ and even $30 \mathrm{ppm}$ or higher. CO exposure can cause adverse health effects, such as (i) at low concentrations, there are impacts on cardiovascular and neurobehavioral processes; and (ii) at high concentrations, unconsciousness or death [64].

Carbon dioxide $\left(\mathrm{CO}_{2}\right)$, a colorless and odorless gas, is a well-known constituent of the earth's atmosphere and also a major human metabolite [65]. The average $\mathrm{CO}_{2}$ concentration in ambient air is about 400 ppm, which is primarily the result of the combustion of fossil fuels $[65,66]$. Recently, the indoor $\mathrm{CO}_{2}$ level has been applied as a reference for the assessment of IAQ as well as for ventilation control [66-68]. According to the ASHRAE standard, it is recommended that indoor $\mathrm{CO}_{2}$ concentrations are below $700 \mathrm{ppm}$ to ensure human health [69]. It is established that exposure to a a $\mathrm{CO}_{2}$ concentration of 3000 ppm increases headache intensity, sleepiness, fatigue, and concentration difficulty $[65,70]$.

\subsection{Toxic Metals}

Heavy metals are released into the atmosphere through either human activities or natural processes [71]. IAP by heavy metals has various causes, including infiltration of outdoor pollutants (dust and soil), smoking, fuel consumption products, and building materials [55]. Heavy metals in indoor dust, entering the human body through inhalation, ingestion, or dermal contact, can have adverse effects on human health [72,73]. According to the International Agency for Research on Cancer (IARC), heavy metals in indoor air are classified into two main groups based on their effects on humans: (i) Non-carcinogenic elements, including cobalt (Co), aluminum (Al), copper ( $\mathrm{Cu}$ ), nickel (Ni), iron $(\mathrm{Fe})$, and zinc $(\mathrm{Zn})$; and (ii) both carcinogenic and non-carcinogenic elements encompassing arsenic (As), chromium $(\mathrm{Cr})$, cadmium $(\mathrm{Cd})$, and lead $(\mathrm{Pb})$ [74]. These common heavy metals (i.e., As, $\mathrm{Cr}$, $\mathrm{Cd}, \mathrm{Pb})$ are likely to cause cancers $[75,76]$, while $\mathrm{Cd}$ and $\mathrm{Pb}$, along with some others, can cause carcinogenic effects, such as cardiovascular disease, slow growth development, and damage to the nervous system $[73,77,78]$. It has been reported that $\mathrm{Pb}$ levels in indoor air can fluctuate from 5.80 to $639.10 \mu \mathrm{g} / \mathrm{g}$, while the highest levels of $\mathrm{As}, \mathrm{Al}, \mathrm{Cr}, \mathrm{Cd}, \mathrm{Co}, \mathrm{Cu}, \mathrm{Ni}, \mathrm{Fe}$, and $\mathrm{Zn}$ are about 486.80, 7150.00, $254.00,8.48,43.40,513.00,471.00,4801.00$, and $2293.56 \mu \mathrm{g} / \mathrm{g}$, respectively [74].

\subsection{Aerosols}

Indoor aerosols are either primary aerosols originating from different indoor sources or secondary aerosols formed by indoor gas-to-particle reactions [79]. Moreover, outdoor particles infiltrating indoors are also likely to be a source of indoor aerosols. Secondary inorganic aerosols are PMs consisting of inorganic elements, including anthropogenic or crustal sources and water-soluble ions [6], while secondary organic aerosols (SOAs) are formed in the gas-to-particle conversion process of VOCs [80]. Additionally, carbonaceous aerosols, which comprise SOAs and elemental carbons released in incomplete combustion, are well-known species in $\mathrm{PM}_{2.5}$ [81]. Biological aerosols (bioaerosols) are a subset of atmospheric PMs comprising dispersal units (fungal spores and plant pollen), microorganisms (bacteria and archaea), 
or cellular materials [82]. Due to their diversity in terms of compounds and phases (gas, liquid, or solid), aerosols can be regarded as dynamic systems [83]. As such, their particle size distribution varies from the nucleation mode ( $<30 \mathrm{~nm}$ in vacuum cleaning condition) to the accumulation mode ( $100 \mathrm{~nm}$, indoor combustion aerosols from smoking, cooking, or incense burning), and to the fine and coarse modes ( $>1 \mu \mathrm{m}$, resuspension aerosols) $[84,85]$. Aerosol exposure through inhalation in the indoor environment has been linked to numerous adverse health effects, mainly in the lungs (the entrance to the human body) and other important target organs, such as the heart and brain [79].

\subsection{Radon}

The primary sources of indoor radon include building materials, soil gas, and tap water [86]. As soil contains radium at trace concentrations, radon is likely to be one of the constituents in the gas filling soil pores. As for radon emissions from building materials, all materials holding trace amounts of radium can release radon. Among building materials, masonry materials (i.e., stone, concrete, and brick) are the main sources for indoor radon emission, in that tons of such materials are used in building construction. Indoor radon can be released through the usage of water from underground water sources containing granite or other radium-bearing rock, and such water sources commonly contain radon concentrations above 10,000 pCi/L [87]. Finally, outdoor air is also regarded as a source of indoor radon [88]. Human exposure to radon in buildings is incurred mainly through the permeation pathways of underlying soil gas [89]. Epidemiological studies have demonstrated that indoor radon can cause lung cancer risk increases of $3 \%$ to $14 \%$, depending on the average radon level [90].

\subsection{Pesticides}

These days, inorganic and organic pesticides have commonly been utilized as protectants for wooden building materials by impregnation or surface coating [91]. Pesticides are also used to control and prevent pests, including bacteria, fungi, insects, rodents, and other organisms [92,93]. In the indoor environment, pesticides are usually semi-volatile compounds that may exist in either gas or particulate form according to properties, such as the vapor pressure, product viscosity, and water solubility [94]. In addition, it has been indicated that carpet and textiles are likely to play the role of long-term reservoirs for organochlorine pesticides $[95,96]$. It is supposed that when used in carpets, textiles, and cushioned furniture, pesticides in fibers will migrate into polyurethane foam pads $[97,98]$, and thus carpet, textiles, and cushioned furniture can reflect an integrated pesticide exposure during their lifetime. Moreover, pesticides are able to enter buildings from outdoors. Once inside, they can persist for months or years due to their protection against sunlight, extreme temperatures, rain, and other factors [97]. Dermal uptake, ingestion, and inhalation of particles or volatile compounds containing pesticides are believed to be potential exposure routes in the indoor environment [92]. Pesticide exposure is associated with adverse health risks, including (i) short-term skin and eye irritation, dizziness, headaches, and nausea; and (ii) long-term chronic impacts, such as cancer, asthma, and diabetes [99].

\subsection{Biological Pollutants}

Biological pollutants in indoor environments include biological allergens (e.g., animal dander and cat saliva, house dust, cockroaches, mites, and pollen) and microorganisms (viruses, fungi, and bacteria) [100]. Biological allergens, known as antigens, originate from a number of insects, animals, mites, plants, or fungi, and will induce an allergic state in reacting with specific immunoglobulin $\mathrm{E}$ (IgE) antibodies [101]. Indoor sources of allergens mainly include furred pets (dog and cat dander), house dust mites, molds, plants, cockroaches, and rodents [102], and there are outdoor sources as well [101]. Viruses and bacteria often originate from or are carried by people and animals. It has been demonstrated that exposure to biological allergens can result in sensitization, respiratory infections, respiratory allergic diseases, and wheezing [103], while exposure to bacteria and viruses indoors is likely to cause noninfectious and infectious adverse health outcomes [104]. 
Table 1. Common indoor pollutants and their effects on human health.

\begin{tabular}{|c|c|c|c|}
\hline Pollutants & Sources & Health Impacts & Refs \\
\hline PM & $\begin{array}{l}\text { Outdoor environment, cooking, combustion activities (burning of candles, use of } \\
\text { fireplaces, heaters, stoves, fireplaces and chimneys, cigarette smoking), cleaning activities }\end{array}$ & $\begin{array}{c}\text { Premature death in people with heart or lung disease, nonfatal } \\
\text { heart attacks, irregular heartbeat, aggravated asthma, } \\
\text { decreased lung function, increased respiratory symptoms }\end{array}$ & {$[7,25-27]$} \\
\hline $\mathrm{NO}_{2}$ & Gas-fueled cooking and heating appliances & $\begin{array}{l}\text { - Enhanced asthmatic reactions } \\
\text { - Respiratory damage leading to respiratory symptoms }\end{array}$ & [46] \\
\hline $\mathrm{O}_{3}$ & Outdoor sources, photocopying, air purifying, disinfecting devices & $\begin{array}{l}\text { DNA damage, lung damage, asthma, decreased respiratory } \\
\text { functions }\end{array}$ & {$[51,52]$} \\
\hline $\mathrm{SO}_{2}$ & Cooking stoves; fireplaces; outdoor air & $\begin{array}{l}\text { - Impairment of respiratory function } \\
\text { - Asthma, chronic obstructive pulmonary disease (COPD), and } \\
\text { cardiovascular diseases }\end{array}$ & [60] \\
\hline $\mathrm{CO}_{\mathrm{x}}$ & $\begin{array}{l}\text { Cooking stoves; tobacco smoking; fireplaces; generators and other gasoline powered } \\
\text { equipment; outdoor air }\end{array}$ & Fatigue, chest pain, impaired vision, reduced brain function & {$[64,105]$} \\
\hline Aerosols & $\begin{array}{l}\text { Tobacco smoke, building materials, consumer products, incense burning, cleaning and } \\
\text { cooking }\end{array}$ & $\begin{array}{l}\text { Cardiovascular diseases, respiratory diseases, allergies, lung } \\
\text { cancer, irritation and discomfort }\end{array}$ & {$[6,108,109]$} \\
\hline Radon (Rn) & $\begin{array}{l}\text { Soil gas, building materials, and tap water } \\
\text { Outdoor air }\end{array}$ & Lung cancer & {$[86,89,90]$} \\
\hline Pesticides & $\begin{array}{l}\text { - Termiticides, insecticides, rodenticides, fungicides, disinfectants and herbicides } \\
\text { - Building materials: carpet, textiles, and cushioned furniture } \\
\text { - Outdoor environment }\end{array}$ & $\begin{array}{l}\text { Irritation to eye, nose and throat; } \\
\text { Damage to central nervous system and kidney; } \\
\text { Increased risk of cancer }\end{array}$ & {$[92,93,97,98]$} \\
\hline Biological allergens & $\begin{array}{l}\text { House dust, pets, cockroaches, mold/dampness, pollens originating from animals, insects, } \\
\text { mites, and plants }\end{array}$ & $\begin{array}{c}\text { Asthma and allergies } \\
\text { Respiratory infections, sensitization, respiratory allergic } \\
\text { diseases and wheezing }\end{array}$ & {$[100,103]$} \\
\hline Microorganism & Bacteria, viruses, and fungi are carried by people, animals, and soil and plants & $\begin{array}{l}\text { Fever, digestive problems, infectious diseases, chronic } \\
\text { respiratory illness }\end{array}$ & {$[100,104]$} \\
\hline
\end{tabular}




\section{IAQ Guidelines and Standards}

It is obvious that the combination of long-term exposure and anthropogenic indoor activities can cause degradation of IAQ and significant risks to human health, even at low air pollutant concentrations. To face these IAQ problems, relevant organizations as well as the scientific community have attempted to develop and apply IAQ standards and guidelines. After many efforts, the world community established IAQ guidelines and standards based on an integrated building approach [110]. According to the WHO and USEPA, the role of IAQ guidelines is to provide a critical database as a reference for the prevention of harmful consequences of IAP and protection of public health; hence, the goal is to eliminate, or at least minimize, possible risks to human populations [111]. Table 2 summarizes the IAQ guidelines of the WHO and USEPA for some common pollutants [112]. However, it is necessary to distinguish non-occupational (i.e., residential houses, schools, offices) guidelines from occupational (industrial) standards [113]. Generally, the WHO and USEPA guidelines are the maximum concentrations during specific durations (i.e., $1 \mathrm{~h}, 24 \mathrm{~h}$, or 1 year). Moreover, the IAQ guidelines of the WHO and USEPA seem non-applicable to occupational sectors [114], as they usually are applied for the control of IAQ inside households, schools, hospitals, public buildings, and offices [47]. In addition, each country will formulate specific standards or guidelines suitable to their own particular circumstances $[115,116]$.

Table 2. Indoor air quality guidelines for major indoor air pollutants.

\begin{tabular}{|c|c|c|c|}
\hline Pollutants & Concentration Levels $\left(\mathrm{mg} / \mathrm{m}^{3}\right)$ & Exposure Time & Organization \\
\hline \multirow{6}{*}{$\mathrm{CO}$} & 100 & $15 \min$ & \multirow{4}{*}{ WHO } \\
\hline & 60 & $30 \mathrm{~min}$ & \\
\hline & 30 & $1 \mathrm{~h}$ & \\
\hline & 10 & $8 \mathrm{~h}$ & \\
\hline & 29 & $1 \mathrm{~h}$ & \multirow{2}{*}{ USEPA } \\
\hline & 10 & $8 \mathrm{~h}$ & \\
\hline $\mathrm{CO}_{2}$ & 1800 & $1 \mathrm{~h}$ & WHO \\
\hline \multirow{3}{*}{$\mathrm{NO}_{2}$} & 0.4 & $1 \mathrm{~h}$ & \multirow{2}{*}{ WHO } \\
\hline & 0.15 & $24 \mathrm{~h}$ & \\
\hline & 0.1 & 1 year & USEPA \\
\hline \multirow{2}{*}{ PM } & 0.15 & $24 \mathrm{~h}$ & \multirow{2}{*}{ USEPA } \\
\hline & 0.05 & 1 year & \\
\hline \multirow{3}{*}{$\mathrm{O}_{3}$} & $0.15-0.2$ & $1 \mathrm{~h}$ & \multirow{2}{*}{ WHO } \\
\hline & $0.1-0.12$ & $8 \mathrm{~h}$ & \\
\hline & 0.235 & $1 \mathrm{~h}$ & USEPA \\
\hline \multirow{4}{*}{$\mathrm{SO}_{2}$} & 0.5 & $10 \mathrm{~min}$ & \multirow{2}{*}{ WHO } \\
\hline & 0.35 & $1 \mathrm{~h}$ & \\
\hline & 0.365 & $24 \mathrm{~h}$ & \multirow{2}{*}{ USEPA } \\
\hline & 0.08 & 1 year & \\
\hline \multirow{2}{*}{$\mathrm{Pb}$} & $0.0005-0.001$ & 1 year & WHO \\
\hline & 0.0015 & 3 months & USEPA \\
\hline Xylene & 8 & $24 \mathrm{~h}$ & WHO \\
\hline Formaldehyde & 0.1 & $30 \mathrm{~min}$ & $\mathrm{WHO}$ \\
\hline Radon & $100 \mathrm{~Bq} / \mathrm{m}^{3}$ & 1 year & $\mathrm{WHO}$ \\
\hline
\end{tabular}

(Source: European Commission DG XVII: https://www.europeansources.info/corporate-author/europeancommission-dg-Xvii/).

\section{The Oxidative Capacity of Indoor Environment}

The oxidative capacity has been significantly less explored in indoor environments. However, recent studies in atmospheric science have started looking at indoor oxidants and their 
precursors, in which the combination of indoor oxidants and their precursors will be referred to as "oxidants" [117]. It has been supposed that ozone $\left(\mathrm{O}_{3}\right)$, the hydroxyl radical $(\mathrm{OH})$, and the nitrate radical $\left(\mathrm{NO}_{3}\right)$ are major oxidants* [118]. In addition, hydrogen peroxide $\left(\mathrm{H}_{2} \mathrm{O}_{2}\right)$, nitrogen dioxide $\left(\mathrm{NO}_{2}\right)$, hydroperoxy radicals $\left(\mathrm{HO}_{2}\right)$, chlorine atoms $(\mathrm{Cl})$, and alkylperoxy radicals $\left(\mathrm{RO}_{2}\right)$ can be important indoor oxidants* under certain conditions. Oxidation is regarded as the dominant process in ozone reactions indoors; thus, most research into indoor oxidants* has focused solely on ozone. Recently, it was demonstrated that the formation of $\mathrm{OH}$ radicals by formaldehyde $(\mathrm{HCHO})$ and photolysis of nitrous acid (HONO) is an important source of indoor oxidants* (Figure 1) [117]. In the atmosphere, the $\mathrm{OH}$ radical is known as the key species in photo-oxidation cycles; it can oxidize VOCs to form secondary aerosols or other gas species, which can cause toxic and carcinogenic effects in humans [119]. As for the important formation pathways of $\mathrm{OH}$ radicals, there are several different reactions productive of $\mathrm{OH}$ radicals, such as (i) $\mathrm{NO}$ and hydroperoxyl $\left(\mathrm{HO}_{2}\right)$, (ii) ozone and alkenes, and (iii) the photolysis reaction of ozone $(\lambda<320 \mathrm{~nm}), \mathrm{HONO}(\lambda<400 \mathrm{~nm})$, and $\mathrm{H}_{2} \mathrm{O}_{2}(\lambda<360 \mathrm{~nm})$ [120].

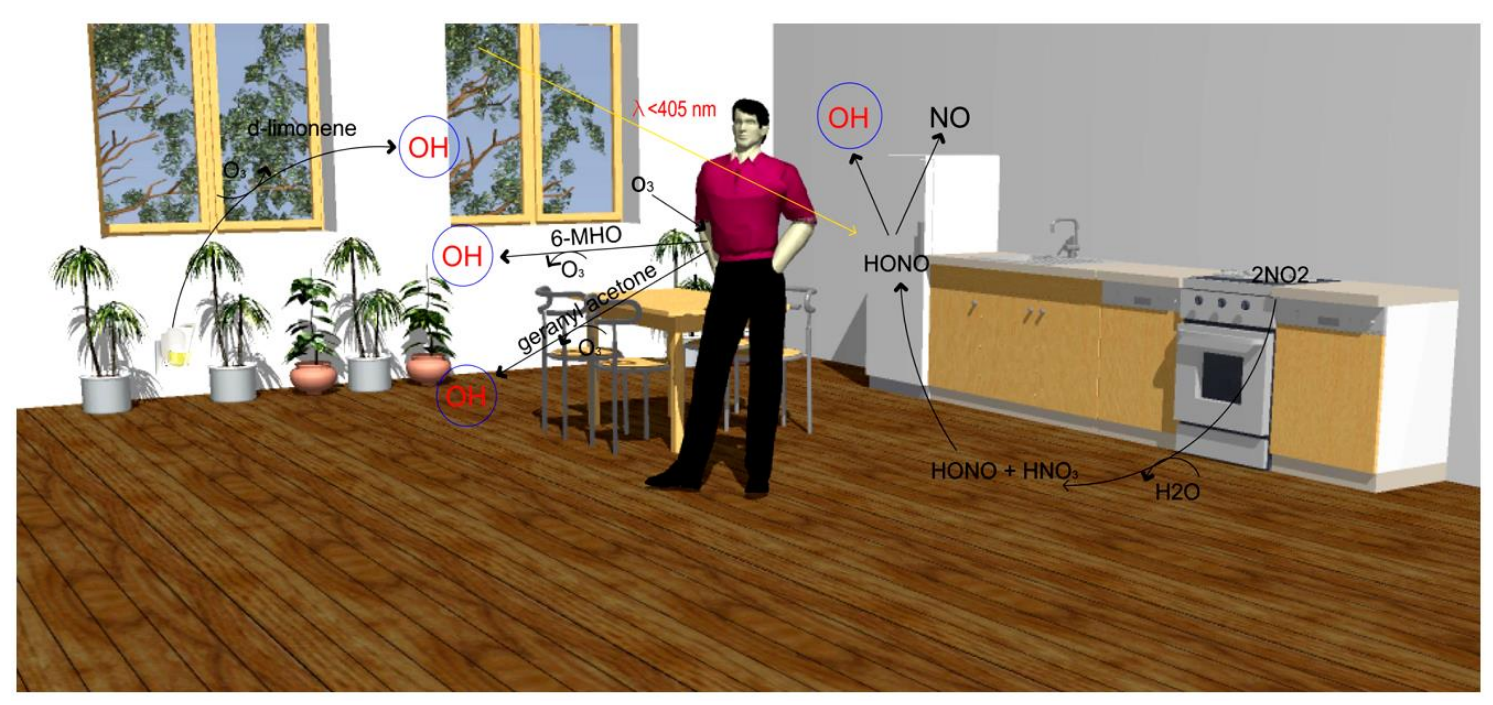

Figure 1. Schematic illustration of the important formation pathways of $\mathrm{OH}$ radicals indoors. Reproduced with permission from [118].

The primary sources of emissions of indoor oxidants* are building materials [121,122] and electronics [123]. Besides, acetaldehyde and other carbonyls can be emitted from human and microbial occupants [121,124,125], and moreover, human activities (i.e., cleaning or disinfection of surfaces, the use of air fresheners, cooking, smoking, vaping, bleach cleaning) are likely to be major sources of indoor oxidants* [117]. Other important sources are secondary oxidant formation indoors and transport from outdoors [50]. Greater outdoor-to-indoor transport of $\mathrm{O}_{3}$ and $\mathrm{NO}$ can lead to heightened $\mathrm{NO} / \mathrm{HO}_{2}$ and $\mathrm{O}_{3}$ /alkene reactions that result in higher levels of $\mathrm{OH}$ radicals.

\section{The Effects of Indoor Air Pollution to Human Health}

\subsection{Building-Associated Illness}

Over the past decades, various symptoms and illnesses have been linked to diminished IAQ in buildings and houses. Indoor exposure to inorganic, organic, physical, and biological contaminants, though often at low levels, is common, ubiquitous, and sustained. Therefore, the harmful effects of IAP on human health have always attracted great attention and concern. According to the WHO, building-associated illness refers to any illness caused by indoor environmental factors, which commonly are divided into two categories: Sick building syndrome (SBS) and building-related illness (BRI) [10]. Their associated symptoms are shown in Figure 2. 


\section{Sick Building Syndrome (SBS)}

- Mucous membrane irritation: eye, nose, and throat irritation;

- Neurotoxic effects: headaches, mental fatigue, reduced memory, nausea, tiredness, dizziness, and irritability;

- Asthma and asthma-like symptoms: chest tightness and wheezing;

- Skin dryness and irritation, gastrointestinal complaints, and others.

\section{Building Related IIIness} (BRI)

- Flu: fever, chills, chest tightness, muscle aches and cough

- Legionnaires' disease, hypersensitivity pneumonitis, humidifier fever

- Lung and respiratory
problems

Figure 2. The common symptoms of sick building syndrome (SBS) and building related illness (BRI).

\subsubsection{Sick Building Syndrome (SBS)}

SBS often refers to a group of symptoms that are linked to the physical environments of specific buildings [126]. Acute health and comfort effects of SBS will appear when patients spend a certain amount or duration of time in a building, but they and their causes are difficult to clearly identify [126]. These effects are either localized in particular areas or widespread throughout a building $[127,128]$. It has been reported that symptoms tend to worsen as a function of the exposure time in buildings and can disappear as people spend more time away from the building [129]. According to the WHO, SBS symptoms caused by IAP can be divided into four categories: (i) Mucous-membrane irritation: Eye, throat, and nose irritation; (ii) neurotoxic effects: Headaches, irritability, and fatigue; (iii) asthma and asthma-like symptoms: Chest tightness and wheezing; and (iv) skin irritation and dryness, gastrointestinal problems (i.e., diarrhea), and others [130,131]. The International Labour Organization (ILO) reported that infants, the elderly, persons with chronic disease, and most urban dwellers of any age have higher health risks linked with IAP-associated SBS symptoms [132]. A low ventilation rate, building dampness, and high room temperature also tend to increase the likelihood of SBS prevalence [133]. Moreover, other risk factors, such as gender, atopy, and psychosocial factors, also have a significant influence on SBS symptom prevalence [134].

\subsubsection{Building-Related Illness (BRI)}

BRI describes illnesses and symptoms with an identified causative agent directly related to exposure to poor air quality in buildings. It is known that causative agents can be chemicals, such as formaldehyde, xylene, pesticides, and benzene, but biological agents are more widespread. In buildings, the typical sources for indoor emissions of biological contaminants are cooling towers, humidification systems, filters, drain pans, wet surfaces, and water-damaged building materials [10]. BRI symptoms have been associated with the flu, including fever, chills, chest tightness, muscle aches, and cough. In addition, serious lung and respiratory problems are likely to occur. Common BRI illnesses include Legionnaires' disease, hypersensitivity pneumonitis, and humidifier fever [10]. It was reported that indoor environmental pollutants can cause BRI symptoms via four major mechanisms: (i) Immunologic, (ii) infectious, (iii) toxic, and (iv) irritant [135]. An irritant effect is often BRI's initial insult, but toxic, allergic, or infectious mechanisms can arise subsequently, depending on the pollutant type and individual susceptibility. Psychologic mechanisms are often not paid significant attention but are demonstrably likely to increase the overall morbidity of building-related diseases as well [136].

Four main factors have been linked to BRI, including: (i) Physical-environmental factors, (ii) chemical factors, (iii) biological factors, and (iv) psychosocial factors. As for the physical-environmental factors, BRI can be influenced by the temperature, humidity, lighting, air 
movement, and dust concentration. The chemical factors, meanwhile, include various pollutants released from human activities and products, such as carpets, paint, new furniture, smoking, cosmetics, asbestos, drapes, and insecticides. Finally, major biological factors associated with BRI are microorganisms as mentioned in Section 3.11.

\subsection{Acute Respiratory Infection}

The respiratory system is frequently the primary target of IAP effects because pollutants often enter into the human body through inhalation. Depending on the area of the affected respiratory tract, acute respiratory infections can be classified into acute lower respiratory infections (ALRIs) and upper respiratory infections (URIs) [137]. URIs are illnesses involving the upper respiratory with common symptoms, such as cough, sinusitis, and otitis media [138], and they are often mild in nature and caused by biological pollutants (viruses, bacteria, fungi, fungal spores, and mites). Meanwhile, ALRI, an acute infection of the lung, is caused by viruses or bacteria, resulting in lung inflammation [137]. It has been found that IAP increases the risk of childhood ALRI by 78\%, which leads to a million deaths in children under 5 years of age every year [139]. This may be because children have a relatively large lung surface area [140]. It has been demonstrated that children living in buildings using solid fuels possess a higher risk of developing ALRI by 2-3 times more than those combusting clean fuels [141]. IAP adversely affects specific and nonspecific host defenses of the respiratory tract against pathogens. In addition, IAP enhances the severity of respiratory infections and also results in high rates of chronic bronchitis of cooking mothers [142].

\subsection{Pulmonary Diseases}

Inhaled air pollutants are associated with allergic diseases and pulmonary diseases, such as asthma, atopic dermatitis, and allergic rhinitis. Moreover, smoking activity is regarded as one of the most important factors in the development of chronic inflammatory pulmonary diseases, including chronic obstructive pulmonary disease (COPD), asthma, and lung cancer [143]. Maximal obtainment of lung function can be significantly affected by IAP exposure; subsequently, lung function is declined. Noxious particles, including PM and CO, may influence lung development starting in utero [144].

COPD diseases are featured by an enhanced chronic inflammatory response in the airways and the lung to toxic PM or indoor air pollutants. It has been demonstrated that women, especially in developing countries, have a great risk for COPD because of exposure to household smoke from cooking [145]. PMs from fossil fuel combustion induce inflammation in the lung and highly reduce the pulmonary function. It has been indicated that fuel smoke in the household can cause COPD diseases with clinical signs and mortality similar to that of tobacco smokers [146]. Fuel burning generates chemical compounds with a high oxidative capacity that induce oxidative stress and DNA damage, which are pointed as the main mechanism responsible for the pathogenesis of COPD [147]. Additionally, biological factors, such as allergens, viruses, and bacterial substances, are likely to induce severe inflammatory reactions and cause immune dysfunction and chronic inflammation, which leads to COPD diseases [148-150].

Exposure to indoor air pollutants is able to result in asthma symptoms or cause asthma exacerbations [151]. It has been indicated that acute exposure to combustion smoke can induce bronchial irritation, inflammation, and enhance bronchial reactivity, which is regarded as the main mechanism responsible for asthma exacerbation, especially in children [152]. It has been demonstrated that children between 5 and 14 years living in houses combusting coal, wood, and kerosene have a relative risk of 1.6 in asthma exacerbation [153].

Lung cancer is usually associated with smoking. Recently, it has been demonstrated that lung cancer is highly linked to IAP exposure in females due to spending long times cooking [154] and thus lung cancer is more popular in females than males in non-smoking cases. Moreover, it has also been indicated that there is a considerable difference in the percentages of non-smoking females with lung cancer based on the various regions. For illustration, more than $80 \%$ of female lung cancer cases in 
east and south Asia are not related to smoking, whereas it is only $15 \%$ in the USA [155]. Emissions from the combustion of solid fuels for cooking or heating have been associated with a high risk of lung cancer [156]. It has been demonstrated that people using solid fuel, such as coal and wood, for heating and cooking throughout their life have a 4 times higher risk of lung cancer as compared with those combusting clean energy [156]. It is the incomplete combustion that highly emits various particle and gaseous carcinogens, including $\mathrm{SO}_{2}, \mathrm{CO}, \mathrm{NO}_{2}, \mathrm{PAHs}$, formaldehyde, heavy metals, and $\mathrm{PM}_{2.5}$ [157]. These pollutants have been found to be related to morbidity and mortality from respiratory diseases, especially lung cancer [158].

\subsection{Cardiovascular Diseases (CVDs)}

The use of solid fuels in households can emit various pollutants that are linked to CVDs, including PM, PAHs, CO, heavy metals, and other organic pollutants [159]. Exposure to $\mathrm{PM}_{2.5}$ increases the incidences of specific acute CVDs, such as ischemic stroke, myocardial infarction, cardiac arrhythmia, heart failure, and atrial fibrillation [160,161]. It has been reported that PM can cause CVDs due to inducing oxidative stress, systemic inflammation, increased blood coagulability, and autonomic and vascular imbalance [162]. PM is also a main factor causing significant increases in fibrinogen, platelet activation, plasma viscosity, and release of endothelins, a family of potent vasoconstrictor molecules. Moreover, $\mathrm{CO}$ in the indoor air environment is likely to influence tissue oxygenation through carboxyhemoglobin production, which results in a high impact on cardiovascular function [141]. Additionally, exposure to $\mathrm{PAH}$ and $\mathrm{Pb}$ from the use of fuel for cooking also enhances oxidative damage, stimulates the renin-angiotensin system, and downregulates nitric oxide [163]. These mechanisms may cause increased vascular tone and peripheral vascular resistance.

\section{Current Strategies for Monitoring and Control of IAQ}

\subsection{Development of Materials for IAQ Sensors}

During the past decade, two-dimensional (2-D) nanostructured materials, due to their unique physical and chemical properties, have attracted great attention for their utility in the design and production of gas-sensing devices. It was demonstrated that 2-D materials possess outstanding features, such as a large surface-to-volume ratio, excellent semiconducting properties, and high surface sensitivity. Moreover, the combination of 2-D nanostructured materials with other-dimensional materials is also proposed as a promising approach to the development of high-performance IAQ-monitoring sensors [164]. It has been demonstrated that 2-D nanostructured materials can be combined with 3-D bulk materials, 2-D nanostructures, 1-D nanostructures, and 0-D nanomaterials to produce 4 novel architectures for IAQ monitoring (Figure 3). Due to their special optical and electrochemical properties, 0-D nanomaterials of nanoscale $(<100 \mathrm{~nm})$ size, such as quantum dots (QDs), nanoparticles, nanocrystals, and nanoclusters, have been applied to the production of photonic, electronic, and chemical-sensing devices $[165,166]$. The use of 1-D nanostructures, such as nanotubes, nanowires (NWs), nanofibers, and nanorods, in combination with 2-D materials has been demonstrated to be effective in numerous IAQ-sensing applications, owing especially to their fast electron-transport capability, special morphology, and high surface-to-volume ratio [167]. Meanwhile, due to the formation of Van der Waals heterostructures through direct stacking of different 2-D materials, various types of 2-D-2-D heterostructures, including black phosphorus/MoSe 2 , graphene/MoS 2 , and graphene/ $\mathrm{WS}_{2} /$ graphene, have been applied in novel devices for IAQ monitoring [168,169]. Finally, by growing or transferring 2-D materials onto bulk 3-D semiconductors, layered 2-D-nanostructured semiconductors can be integrated with traditional bulk 3-D semiconductor substrates in the design of new gas-sensing devices [167]. In summary, heterostructure-based devices, given the superior properties of their constituent materials, could be utilized for a wide range of IAQ detection applications. 


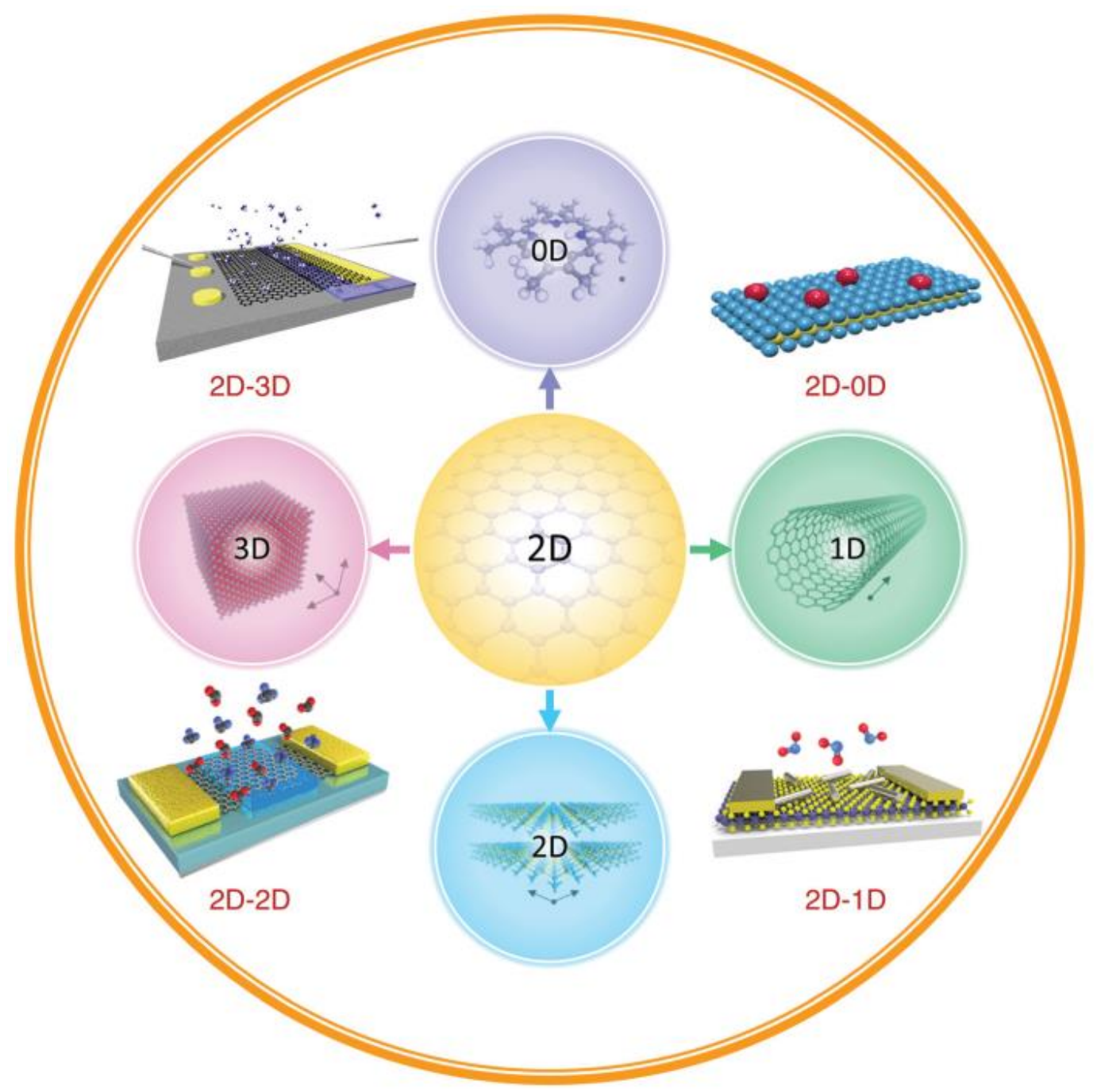

Figure 3. Schematic overview of 2-D nanostructured materials and different types of heterostructures with 0-D, 1-D, 2D, and 3-D materials used for gas-sensing applications. Reproduced with permission from [164].

The development of inexpensive sensor networks and systems has emerged as a key strategy for the monitoring of IAQ. Metal oxide (MOx) sensors are currently regarded as one of several outstanding technologies, especially in consideration of their low cost, high sensitivity, simplicity, and compatibility with modern electronic devices [170]. With their small size and low cost, they are ideally suited for remote and portable monitoring systems. Recently, metal oxide semiconductor gas sensors have been considered as a viable platform for the detection of VOCs and $\mathrm{CO}$ in the indoor air environment [171-173]. It is reported that several metal oxides, including $\mathrm{SnO}_{2}, \mathrm{ZnO}, \mathrm{TiO}_{2}, \mathrm{In}_{2} \mathrm{O}_{3}$, $\mathrm{Fe}_{2} \mathrm{O}_{3}, \mathrm{MoO}_{3}, \mathrm{Co}_{3} \mathrm{O}_{4}, \mathrm{CuO}, \mathrm{NiO}$, and $\mathrm{CdO}$, have been utilized in IAQ-sensing applications.

\subsection{Advanced Technologies for Monitoring of IAQ}

There have been various techniques invented and introduced for real-time monitoring [174]. Among them, however, wireless sensor network (WSN) and Internet of Things (IoT)-based systems are the most popular technologies developed for IAQ monitoring due to their rising scope in the Industry 4.0 revolution. 


\subsubsection{Internet of Thing (IoT)-Based Systems}

In recent years, with the development of mobile technologies, the Internet of Things (IoT), and big data, machine-learning technologies have been introduced as trending technologies that offer great capability for real-time IAQ monitoring. By the introduction of IoT-based portable IAQ-monitoring devices, these days, air quality can be easily monitored and controlled in real time. Many IoT-based IAQ-monitoring systems and devices have been designed and introduced, including open-source technologies for data processing and transmission [175].

One of the important applications of IoT in IAQ monitoring is "electronic noses" (E-noses), which are biomimetic-type devices that mimic the functionalities of mammals' olfaction system [176]. Generally, an E-nose system consists of four basic components: (i) A multi-sensor array; (ii) software with digital pattern recognition algorithms; (iii) an information-processing unit (i.e., an artificial neural network (ANN)), and (iv) reference library databases [177]. By using the chemical sensor arrays in combination with the classification algorithms, E-noses can easily monitor target gases by detecting and discriminating types and concentrations [178]. Therefore, E-noses have globally attracted great interest for their low-cost portable IAQ-monitoring utility [179]. For example, Tastan et al. proposed a low-cost, portable, IoT-based, and real-time monitoring E-nose system [180], by which a range of sensors can measure different air pollutants (i.e., $\mathrm{CO}_{2}, \mathrm{CO}, \mathrm{PM} 10$, and $\mathrm{NO}_{2}$ ) and air parameters (i.e., temperature and humidity). Especially, the proposed E-nose is produced with open-source, low-cost, and easy installation software and four detection units, including GP2Y1010AU (dust sensor), MH-Z14A $\left(\mathrm{CO}_{2}\right.$ sensor), MICS-4514 ( $\mathrm{NO}_{2}$ and CO sensor), and DHT22 (temperature sensor and humidity sensor). These sensors monitor via the 32-bit ESP32 Wi-Fi controller, while a mobile device interface based on the Blynk IoT platform receives data and records it in a cloud server (Figure 4A). This concept is anticipated to serve as a model for future IAQ-monitoring devices. In other research, Chen et al. developed a high-performance smart E-nose system comprising a multiplexed tin oxide $\left(\mathrm{SnO}_{2}\right)$ nanotube sensor array, a read-out electronic circuit, a mobile phone receiver, a wireless data transmission unit, and a data processing application [181]. Compared with conventional devices, this nanotube sensor exhibited higher sensitivity gas detection and discrimination at room temperature, owing to the use of nanotube sensors possessing a large surface area for interaction with gas molecules. It was demonstrated that this E-nose device can detect indoor target air pollutants by only a simple vector-matching recognition algorithm; hence, it can be regarded as possessing state-of-the-art sensitivity for air pollutant detection at room temperature based on metal oxide sensors. Importantly, therefore, the smart E-nose device and system can be applied for high-performance monitoring of the indoor environment's quality in smart buildings, smart homes, or even smart cities in the present and future (Figure 4B).

Recently, smart devices based on the integration of cloud computing and IoT have been developed to precisely monitor IAQ and efficiently transmit real-time data to a cloud computing-based web server using an IoT sensor network [182,183]. Jo et al. (2020) introduced a Smart-Air device to collect reliable and accurate data for IAQ monitoring (Figure 4C) [184]. The Smart-Air device includes three components: A pollutant detection sensor array, a microcontroller, and an LTE modem. The sensors in the Smart-Air device include a VOC sensor, a laser PM sensor, a $\mathrm{CO}_{2}$ sensor, a $\mathrm{CO}$ sensor, and a temperature/humidity sensor. The Smart-Air platform additionally relies on cloud computing technology and IoT technology to monitor and control IAQ anytime and anywhere. Importantly, the Korean Ministry of Environment testing has demonstrated that the device is highly reliable. All received data is stored in the web server's cloud to provide resources for further analysis of IAQ [184]. 

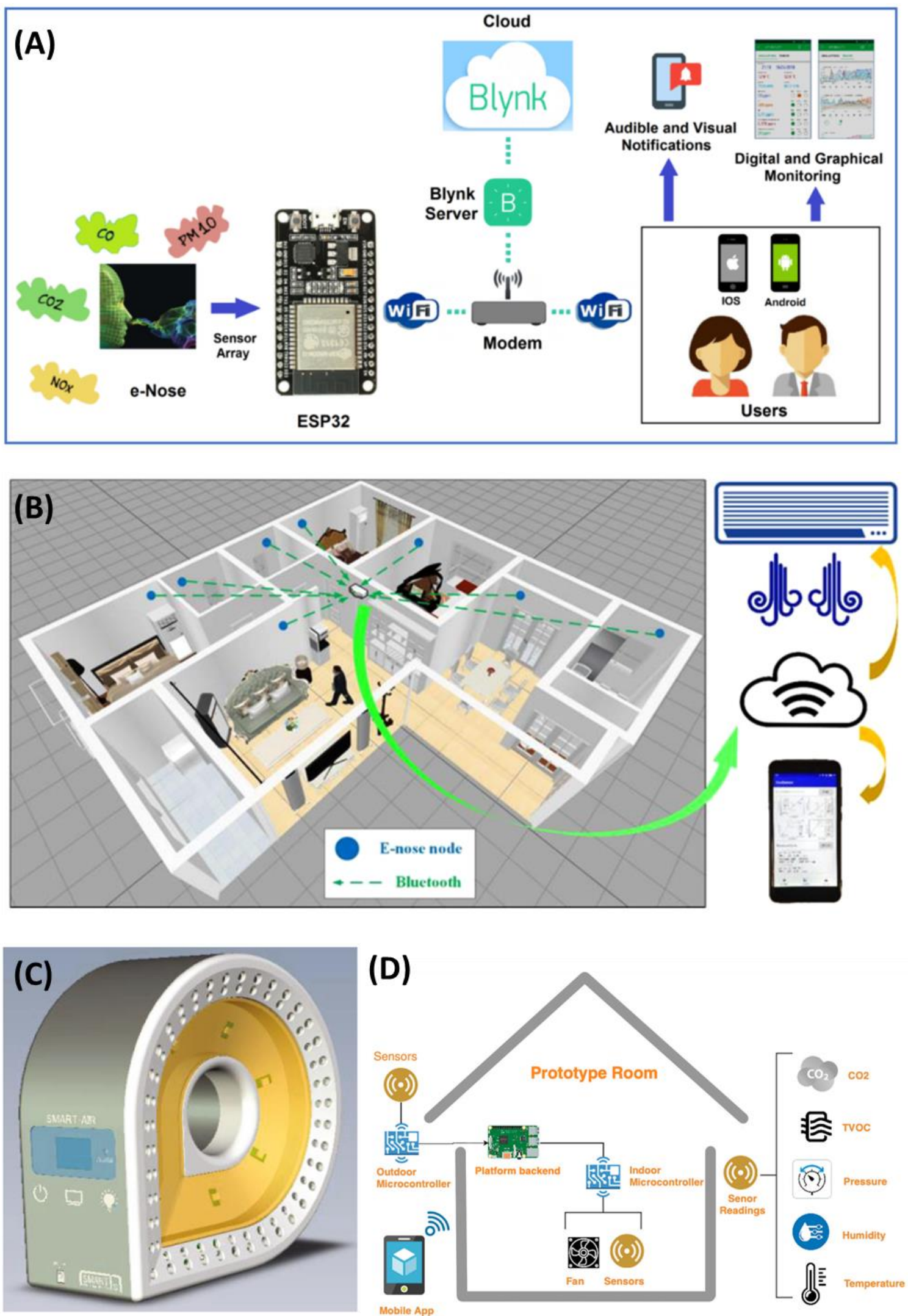

Figure 4. Illustration of the proposed electronics nose (E-nose) system architecture (A); the proposed E-nose application in future smart buildings (B); primitive concept design of Smart-Air (C); and a smart ventilation system for optimizing indoor air quality (IAQ) Levels in buildings (D). Reproduced with permission from $[180,181,183,184]$. 
According to the concept of the combination of ventilation system activation with IAQ-variable-level detection, a strategy for IAP reduction by demand-controlled ventilation systems (DCVs) based on $\mathrm{CO}_{2}$ detection was recently developed [185]. This system consists of four basic components, including the hardware, backend, mobile app, and IAQ index computation. The system operation depends on several real-time sensors and algorithms to accurately and automatically control the ventilation system and maintain a suitable concentration of air pollutants by balancing indoor and outdoor parameters [183]. As shown in Figure 4D, this sensing platform provides an IoT-based system for the control of IAQ levels in a building based on recorded data. Some parameters, such as the $\mathrm{CO}_{2}$, VOCs, humidity, and temperature of both the indoor and outdoor environments, are measured simultaneously; then, this data is applied for computation of the IAQ index, which is used for algorithm-based ventilation control. Additionally, the system allows for observation and management via a mobile app.

\subsubsection{Wireless Sensor Network (WSN)-Based Systems}

In the past few years, the wireless sensor network (WSN) has gained great attention in many different monitoring situations [186]. Generally, WSN is composed of tiny devices or nodes having an important role in collecting information by sensors from the environment as well as wirelessly communicating with other nodes in the system [174]. It has been indicated that in the development strategies of the WSN system, ZigBee, a wireless standard based on the IEEE 802.15.4 specification, is regarded as the most reliable communication protocol because of its low cost, low consumption, and low data rate $[187,188]$. In addition, use of the ZigBee protocol allows networks to work in power-saving mode $[189,190]$.

In practical applications, WSN systems usually include a distributed sensor network connected to a cloud system [191]. ZigBee-based sensor nodes transmit field measurement data to the cloud system through a gateway. The optimized cloud computing systems have often been utilized to monitor, store, process, and visualize the obtained data from the sensor network [187]. Additionally, the obtained data is processed and analyzed by artificial intelligence techniques for optimization of the air pollutant detection. Due to the great number of nodes deployed to provide relevant information of the IAQ distribution in different areas, the WSN systems may significantly enhance the efficiency of air quality monitoring and measurement. The WSN is an automatic IAQ monitoring system with an autonomous, accurate, and simultaneous measurement of IAQ in different areas, which allows the user or the building manager to get data in real time [192]. It has been found that the WSN systems are usually applied for the monitoring and detection of numerous common VOCs, such as benzene, ethylbenzene, toluene, and xylene [191], and a variety of environmental parameters, including, temperature, relative humidity, $\mathrm{CO}, \mathrm{CO}_{2}$, and luminosity [192].

\subsection{Air Purification Technologies for IAQ Improvement}

Control of emission sources, development of air purification technologies, and optimization of ventilation systems are regarded as three main approaches to improve IAQ [193]. Among them, the investigation of novel technologies to filter and purify indoor air pollutants has attracted great attention over the last decade. Adsorption technologies using carbon-based filter media have been known as the leading technologies for removing gas pollutants [194]. There are numerous residential and commercial HVAC filters that have been developed and used in various buildings, i.e., household, shopping mall, school, and office building. It was reported that adsorptive HVAC filters may effectively remove several noxious pollutants, including $\mathrm{O}_{3}$, aerosols, VOCs, and PMs [195]. The HVAC filters can be designed in various shapes, such as filter cassettes made of flat sheet filter media and cartridges inserted by granulated activated carbon or bag filters [196]. However, this technology has exhibited a significant limitation in terms of the adsorption efficiency because its equilibrium adsorption capacity is significantly decreased at sub-ppm concentrations of pollutants [197]. Additionally, it has been demonstrated that the adsorption efficiency of carbon-based filters is remarkably reduced in the 
presence of humidity. Therefore, improvement of the long-term operation and performance of this air filter system is a potential approach in the development strategies of HVAC filters.

Long-term operation can induce the proliferation of molds and the growth of germs, which lead to the effective decrease of the air filters [198]. Non-thermal plasma (NTP) technologies have been demonstrated as an effective solution to resolve these problems. The operation of NTP techniques is based on the generation of a quasi-neutral environment, such as radicals, ions, electrons, and UV photons [199]. Several non-thermal discharge plasma techniques have been developed for the removal of indoor air contaminants, such as $\mathrm{NO}_{x}, \mathrm{SO}_{x}$, and VOCs, including corona discharge [200], dielectric barrier discharge [201], and surface discharge. It has been shown that ozone formed by the electric discharge exhibits a significant germicidal power and the air filter can function as an effective electric precipitator due to electrostatic force. However, NTP technologies also have some disadvantages: (i) Poor energy efficiency; (ii) strong influence of humidity on the performance; and (iii) the formation of secondary hazardous pollutants, such as $\mathrm{CO}, \mathrm{HCHO}$, and $\mathrm{NO}_{x}$ [202]. These drawbacks have limited practical applications of this technique in the indoor air purification.

In the development strategies for indoor air pollution control, advanced oxidation processes (AOPs)-based technologies have attracted great attention due to the minimum generation of secondary pollution. Among them, photocatalysis, which is the process by which indoor air pollutants are disintegrated due to exposing semiconductor photocatalysts under sufficiently energetic irradiation, has been considered as a promising technology [203]. Compared with conventional adsorption technologies, photocatalysis exhibits several outstanding features: (i) Direct degradation of gaseous pollutants (particularly VOCs) into $\mathrm{CO}_{2}$ and $\mathrm{H}_{2} \mathrm{O}$ under ambient conditions; and (ii) applicability for the removal of low-concentration pollutants (sub-ppm levels) [204]. The semiconductors used as photocatalysts in the photocatalysis technology include titanium dioxide $\left(\mathrm{TiO}_{2}\right)$, polymeric (or graphitic), tungsten oxide $\left(\mathrm{WO}_{3}\right)$, carbon nitride $(\mathrm{CN}), \mathrm{Bi}, \mathrm{Ag}$, cadmium sulfide $(\mathrm{CdS})$, metal oxides $\mathrm{MO}_{\mathrm{x}}(\mathrm{M}=\mathrm{Fe}, \mathrm{Zn}, \mathrm{V})$, perovskite, and others [204]. However, due to the low cost, strong oxidative power, and chemical stability, $\mathrm{TiO}_{2}$ has gained more attention for IAP purification [205].

\subsection{Smart Home for IAQ Control}

In recent years, home automation generally and the "smart home" particularly have attracted great interest. Now, the smart home, controllable via smartphone applications and IoT-based wearable devices, is a vital element of smart cities. Its foundation was the proposed home energy management system (HEMS) [206,207]. In fact, originally, the smart home was developed simply to enhance the energy-usage efficiency [208,209] and optimize ventilation technology [21]. However, the term 'smart home' these days is most often associated with various home automation systems, such as home appliances, communications, and entertainment electronics. The future development of smart home technology is likely to proceed in two general directions: (i) The above-mentioned control of ventilation, blinds, and appliances for a reduction of energy costs and enhancement of health, safety, and comfortability; and (ii) assistance of elderly and disabled people by utilization of robotic machines and smart sensor technologies [210]. However, the smart home also offers opportunities to reduce the negative impacts of IAP on human health. Certainly, as smart home technology is increasingly applied in buildings, IAQ and air hygiene will be taken more seriously. Normally, a smart building system consists of three main components: (i) User gateway media, (ii) power supply media, and (iii) controller and devices [206]. User gateway media is a combination of a smartphone application and a supervisory control and data acquisition (SCADA) interface, which allows occupants to monitor and manage appliances remotely through smartphones or computers using Wi-Fi or a wireless module. Power supply media is a novel system that optimizes energy efficiency by using renewable energy sources. Finally, controller and devices provide automatic control of the fan speed, temperature, and air pollutant concentrations. The key to smart buildings is modern sensor technology [211]. By the use of multiple sensors, all climatic parameters and concentrations of polluting substances are recorded automatically and constantly in the SCADA system. Especially, based on the data recorded thereby, 
smart sensor systems can take appropriate action (e.g., adjustment of ventilation settings and/or temperature) to improve IAQ and reduce IAP [210].

\section{Conclusions}

In conclusion, pollutants in the indoor air environment are significant contributing causes of human diseases. There are numerous indoor air pollutants, including PM, VOCs, CO, CO2, ozone, radon, heavy metals, aerosols, pesticides, biological allergens, and microorganisms, all of which can lead to diminished IAQ and thereby harmful effects on human health. Most of these pollutants usually originate from two main sources: (i) Human activities in buildings, such as combustion, cleaning, use of certain building materials in the course of construction or renovation, and operation of electronic machines; and (ii) transportation from outdoor sources. Although these pollutants are often present at only low concentrations in buildings, long-term exposure can cause significant risks to human health. Generally, there are two categories of building-associated illness: Sick building syndrome (SBS) and building-related illness (BRI). To reduce IAP's impacts, many strategies and approaches for the control and reduction of pollutant concentrations have been taken. It is expected that the development of advanced materials for sensors, IAQ-monitoring systems, and the smart home will prove to be effective for the control and enhancement of IAQ into the future.

Author Contributions: Conceptualization, V.V.T. and Y.-C.L.; writing-original draft preparation, V.V.T. and D.P.; writing-review and editing, D.P. and Y.-C.L.; visualization, D.P.; supervision, Y.-C.L.; project administration, D.P. and Y.-C.L.; funding acquisition, D.P. All authors have read and agreed to the published version of the manuscript.

Funding: This research was funded by a grant from the Subway Fine Dust Reduction Technology Development Project of the Ministry of Land Infrastructure and Transport (19QPPW-B152306-01) and the Ministry of Environment as "Korea Environmental Industry \& Technology Institute (KEITI) (No. 2018000120004)".

Conflicts of Interest: The authors declare no conflict of interest.

\section{References}

1. Leech, J.A.; Nelson, W.C.; Burnett, R.T.; Aaron, S.; Raizenne, A.M.E. It's about time: A comparison of canadian and american time-activity patterns. J. Expo. Sci. Environ. Epidemiol. 2002, 12, 427-432. [CrossRef] [PubMed]

2. WHO. Household Air Pollution and Health. Available online: https://www.who.int/en/news-room/factsheets/detail/household-air-pollution-and-health (accessed on 28 January 2020).

3. Kumar, P.; Imam, B. Footprints of air pollution and changing environment on the sustainability of built infrastructure. Sci. Total Environ. 2013, 444, 85-101. [CrossRef] [PubMed]

4. Ekmekcioglu, D.; Keskin, S.S. Characterization of indoor air particulate matter in selected elementary schools in istanbul, turkey. Indoor Built Environ. 2007, 16, 169-176. [CrossRef]

5. Hromadka, J.; Korposh, S.; Partridge, M.C.; James, S.W.; Davis, F.; Crump, D.; Tatam, R.P. Multi-parameter measurements using optical fibre long period gratings for indoor air quality monitoring. Sens. Actuat. B Chem. 2017, 244, 217-225. [CrossRef]

6. Koivisto, A.J.; Kling, K.I.; Hänninen, O.; Jayjock, M.; Löndahl, J.; Wierzbicka, A.; Fonseca, A.S.; Uhrbrand, K.; Boor, B.E.; Jiménez, A.S.; et al. Source specific exposure and risk assessment for indoor aerosols. Sci. Total Environ. 2019, 668, 13-24. [CrossRef] [PubMed]

7. Hamanaka, R.B.; Mutlu, G.M. Particulate matter air pollution: Effects on the cardiovascular system. Front. Endocrinol. 2018, 9, 680. [CrossRef]

8. USEPA. Introduction to Indoor Air Quality. Available online: https://www.epa.gov/indoor-air-quality-iaq/ introduction-indoor-air-quality (accessed on 28 January 2020).

9. Argunhan, Z.; Avci, A.S. Statistical evaluation of indoor air quality parameters in classrooms of a university. Adv. Merteorol. 2018, 2018, 4391579. [CrossRef]

10. USEPA. Fundamentals of Indoor Air Quality in Buildings. Available online: https://www.epa.gov/indoorair-quality-iaq/fundamentals-indoor-air-quality-buildings (accessed on 28 January 2020).

11. Fang, L.; Clausen, G.; Fanger, P.O. Impact of temperature and humidity on the perception of indoor air quality. Indoor Air 2004, 8, 80-90. [CrossRef] 
12. Marć, M.; Śmiełowska, M.; Namieśnik, J.; Zabiegała, B. Indoor air quality of everyday use spaces dedicated to specific purposes-A review. Environ. Sci. Pollut. Res. 2018, 25, 2065-2082. [CrossRef]

13. Peng, Z.; Deng, W.; Tenorio, R. Investigation of indoor air quality and the identification of influential factors at primary schools in the north of china. Sustainability 2017, 9, 1180. [CrossRef]

14. Poupard, O.; Blondeau, P.; Iordache, V.; Allard, A. Statistical analysis of parameters influencing the relationshipbetween outdoor and indoor air quality in schools. Atmos. Environ. 2005, 39, 2071-2080. [CrossRef]

15. Liang, J. Other toxins in the air. In Chemical Modeling for Air Resources: Fundamentals, Applications and Corroborative Analysis; Elsevier: Amsterdam, The Netherlands, 2013; pp. 221-237.

16. Micallef, A.; Caldwell, J.; Colls, J.J. The influence of human activity on the vertical distribution of airborne particle concentration in confined environments: Preliminary results. Indoor Air 1998, 8, 131-136. [CrossRef]

17. Linaker, C.H.; Chauhan, A.J.; Inskip, H.; Frew, A.J.; Sillence, A.; Coggon, D.; Holgate, S.T. Distribution and determinants of personal exposure to nitrogen dioxide in school children. Occup. Environ. Med. 1996, 53, 200-203. [CrossRef] [PubMed]

18. Ström, J.; Alfredsson, L.; Malmfors, T.; Selroos, O. Nitrogen dioxide: Causation and aggravation of lung diseases. Indoor Environ. 1994, 3, 58-68.

19. Awbi, H.B. Ventilation of Buildings; Spon Press: London, UK, 2003.

20. Op't Veld, P. Introduction to ec reshyvent-eu cluster project on demandcontrolled hybrid ventilation for residential buildings. Build. Environ. 2008, 43, 1342-1349. [CrossRef]

21. Chenari, B.; Carrilho, J.D.; Silva, M.G. Towards sustainable, energy-efficient and healthy ventilationstrategies in buildings: A review. Renew. Sustain. Energy Rev. 2016, 59, 1426-1447. [CrossRef]

22. Vornanen-Winqvist, C.; Salonen, H.; Järvi, K.; Andersson, M.A.; Mikkola, R.; Marik, T.; Kredics, L.; Kurnitski, J. Effects of ventilation improvement on measured and perceived indoor air quality in a school building with a hybrid ventilation system. Int. J. Environ. Res. Public Health 2018, 15, 1414. [CrossRef]

23. OSHA. Technical Manual: Indoor air Quality Investigation. Available online: https://www.osha.gov/dts/ osta/otm/otm_iii/otm_iii_2.html (accessed on 28 January 2020).

24. Leung, D.Y.C. Outdoor-indoor air pollution in urban environment: Challenges and opportunity. Front. Environ. Sci. 2015, 2, 69. [CrossRef]

25. USEPA. Indoor Particulate Matter. Available online: https://www.epa.gov/indoor-air-quality-iaq/indoorparticulate-matter (accessed on 28 January 2020).

26. Miller, M.R.; Shaw, C.A.; Langrish, J.P. From particles to patients: Oxidative stress and the cardiovascular effects of air pollution. Future Cardiol. 2012, 8, 577-602. [CrossRef]

27. Brook, R.D.; Rajagopalan, S.; PopeIII, C.A.; Brook, J.R.; Bhatnagar, A.; Diez-Roux, A.V.; Holguin, F.; Hong, Y.; Luepker, R.V.; Mittleman, M.A.; et al. Particulate matter air pollution and cardiovascular disease: An update to the scientific statement from the american heart association. Circulation 2010, 121, 2331-2378. [CrossRef]

28. Ferro, A.R.; Kopperud, R.J.; Hildemann, L.M. Elevated personal exposure to particulate matter from human activities in a residence. J. Expo. Sci. Environ. Epid. 2004, 14, S34-S40. [CrossRef] [PubMed]

29. Wallace, L. Indoor particles: A review. J. Air Waste Manag. Assoc. 1996, 46, 98-126. [CrossRef] [PubMed]

30. Dennekamp, M.; Howarth, S.; Dick, C.A.J.; Cherrie, J.W.; Donaldson, K.; Seaton, A. Ultrafine particles and nitrogen oxides generated by gas and electric cooking. Occup. Environ. Med. 2001, 58, 511-516. [CrossRef] [PubMed]

31. Yu, K.-P.; Yang, K.R.; Chen, Y.C.; Gong, J.Y.; Chen, Y.P.; Shih, H.-C.; Lung, S.-C.C. Indoor air pollution from gas cooking infive taiwanese families. Build. Environ. 2015, 93, 258-266. [CrossRef]

32. Kim, H.; Kang, K.; Kim, T. Measurement of particulate matter (pm2.5) and health risk assessment of cooking-generated particles in the kitchen and living rooms of apartment houses. Sustainability 2018, 10, 843. [CrossRef]

33. Ferro, A.R.; Kopperud, R.J.; Hildemann, L.M. Source strengths for indoor human activities that resuspend particulate matter. Environ. Sci. Technol. 2004, 38, 1759-1764. [CrossRef]

34. USEPA. Volatile Organic Compounds' Impact on Indoor Air Quality. Available online: https:// www.epa.gov/indoor-air-quality-iaq/volatile-organic-compounds-impact-indoor-air-quality (accessed on 28 January 2020). 
35. Huang, Y.; Ho, S.S.H.; Ho, K.F.; Lee, S.C.; Yu, J.Z.; Louie, P.K.K. Characteristics and health impacts of vocs and carbonyls associated withresidential cooking activities in hong kong. J. Hazard. Mater. 2011, 186, 344-351. [CrossRef]

36. Liu, S.; Li, R.; Wild, R.J.; Warneke, C.; Gouw, J.A.d.; Brown, S.S.; Miller, S.L.; Luongo, J.C.; Jimenez, J.L.; Ziemann, P.J. Contribution of human-related sources to indoor volatile organiccompounds in a university classroom. Indoor Air 2016, 26, 925-938. [CrossRef]

37. Lee, K.; Choi, J.-H.; Lee, S.; Park, H.-J.; Oh, Y.-J.; Kim, G.; Lee, W.-S.; Son, B.-S. Indoor levels of volatile organic compounds and formaldehyde from emission sources at elderly care centers in korea. PLoS ONE 2018, 13, e0197495. [CrossRef]

38. Dunagan, S.C.; Dodson, R.E.; Rudel, R.A.; Brody, J.G. Toxics use reduction in the home: Lessons learned from household exposure studies. J. Clean Prod. 2011, 19, 438-444. [CrossRef] [PubMed]

39. Tang, X.; Misztal, P.K.; Nazaroff, W.W.; Goldstein, A.H. Siloxanes are the most abundant volatile organic compound emitted from engineering students in a classroom. Environ. Sci. Technol. Lett. 2015, 2, 303-307. [CrossRef]

40. Chin, J.-Y.; Godwin, C.; Parker, E.; Robins, T.; Lewis, T.; Harbin, P.; Batterman, S. Levels and sources of volatile organic compounds in homes of children with asthma. Indoor Air 2014, 24, 403-415. [CrossRef] [PubMed]

41. Lucattini, L.; Poma, G.; Covaci, A.; Boer, J.d.; Lamoree, M.H.; Leonards, P.E.G. A review of semi-volatile organic compounds (svocs) in the indoorenvironment: Occurrence in consumer products, indoor air and dust. Chemosphere 2018, 201, 466-482. [CrossRef] [PubMed]

42. Okubo, M.; Kuwahara, T. Chapter 5-prospects for marine diesel engine emission control. In New Technologies for Emission Control in Marine Diesel Engines; Elsevier: Amsterdam, The Netherlands, 2020; pp. 211-266.

43. Brickus, L.R.; Cardoso, J.; Neto, F.R.D.A. Distributions of indoor and outdoor air pollutants in rio de janeiro, brazil: Implications to indoor air quality in bayside offices. Environ. Sci. Technol. 1998, 32, 3485-3490. [CrossRef]

44. Weschler, C.J.; Nazaroff, W.W. Svoc exposure indoors: Fresh look at dermal pathways. Indoor Air 2012, 22, 356-377. [CrossRef]

45. Weschler, C.J.; Nazaroff, W.W. Dermal uptake of organic vapors commonly found in indoor air. Environ. Sci. Technol. 2014, 48, 1230-1237. [CrossRef] [PubMed]

46. Bernstein, J.A.; Alexis, N.; Bacchus, H.; Bernstein, I.L.; Fritz, P.; Horner, E.; Li, N.; Mason, S.; Nel, A.; Oullette, J.; et al. The health effects of nonindustrial indoor air pollution. J. Allergy Clin. Immunol. 2008, 121, 585-591. [CrossRef] [PubMed]

47. WHO. Guidelines for Indoor Air Quality: Selected Pollutants; World Health Organization Regional Office for Europe: Bonn, Germany, 2010.

48. Kodama, Y.; Arashidani, K.; Tokui, N.; Kawamoto, T.; Matsuno, K.; Kunugita, N.; Minakawa, N. Environmental NO2 concentration and exposure in daily life along main roads in tokyo. Environ. Res. 2002, 89, 236-244. [CrossRef]

49. Spengler, J.; Samet, J.; McCarthy, J.F. Indoor Air Quality Handbook; McGraw-Hill Professional: New York, NY, USA, 2001.

50. Weschler, C.J. Ozone in indoor environments: Concentration and chemistry. Indoor Air 2000, 10, $269-288$. [CrossRef]

51. Salonen,H.; Salthammer, T.; Morawska, L. Human exposure to ozone in school and office indoor environments. Environ. Int. 2018, 119, 503-514. [CrossRef]

52. Huang, Y.; Yang, Z.; Gao, Z. Contributions of indoor and outdoor sources to ozone in residential buildings in nanjing. Int. J. Environ. Res. Public Health 2019, 16, 2587. [CrossRef] [PubMed]

53. Brown, S.K. Assessment of pollutant emissions from dry-process photocopiers. Indoor Air 1999, 9, $259-267$. [CrossRef] [PubMed]

54. Lee, S.C.; Lam, S.; Fai, H.K. Characterization of vocs, ozone, and pm10 emissions from office equipment in an environmental chamber. Build. Environ. 2001, 36, 837-842. [CrossRef]

55. Zhang, Q.; Jenkins, P.L. Evaluation of ozone emissions and exposures from consumer products and home appliances. Indoor Air 2016, 27, 386-397. [CrossRef] [PubMed]

56. Guo, C.; Gao, Z.; Shen, J. Emission rates of indoor ozone emission devices: A literature review. Build. Environ. 2019, 158, 302-318. [CrossRef] 
57. Weschler, C.J.; Shields, H.C.; Naik, D.V. Indoor ozone exposures. Air Repair 1989, 39, 1562-1568. [CrossRef]

58. Weschler, C.J. Roles of the human occupant in indoor chemistry. Indoor Air 2015, 26, 6-24. [CrossRef]

59. Katsouyanni, K.; Touloumi, G.; Spix, C.; Schwartz, J.; Balducci, F.; Medina, S.; Rossi, G.; Wojtyniak, B.; Sunyer, J.; Bacharova, L.; et al. Short term effects of ambient sulphur dioxide and particulate matter on mortality in 12 european cities: Results from time series data from the aphea project. BMJ 1997, 314, 1658. [CrossRef]

60. Seow, W.J.; Downward, G.S.; Wei, H.; Rothman, N.; Reiss, B.; Xu, J.; Bassig, B.A.; Li, J.; He, J.; Hosgood, H.D.; et al. Indoor concentrations of nitrogen dioxide and sulfur dioxide from burning solid fuels for cooking and heating in yunnan province, china. Indoor Air 2016, 26, 776-783. [CrossRef]

61. Hänninen, O.; Goodman, P. Outdoor air as a source of indoor pollution. In Indoor Air Pollution; The Royal Society of Chemistry: London, UK, 2019; pp. 35-65.

62. WHO. Air Quality Guidelines: Chapter 7.4 Sulfur Dioxide; WHO Regional Office for Europe: Copenhagen, Denmark, 2000.

63. International Programme on Chemical Safety. Carbon Monoxide; World Health Organization: Geneva, Switzerland, 1999.

64. Raub, J.A.; Mathieu-Nolf, M.; Hampson, N.B.; Thom, S.R. Carbon monoxide poisoning-A public health perspective. Toxicology 2000, 145, 1-14. [CrossRef]

65. Zhang, X.; Wargocki, P.; Lian, Z.; Thyregod, C. Effects of exposure to carbon dioxide and bioeffluents on perceivedair quality, self-assessed acute health symptoms and cognitiveperformance. Indoor Air 2017, 27, 47-64. [CrossRef] [PubMed]

66. Persily, A.; de Jonge, L. Carbon dioxide generation rates for building occupants. Indoor Air 2017, $27,868-879$. [CrossRef] [PubMed]

67. Emmerich, S.J.; Persily, A.K. State-of-the-Art Review of $\mathrm{CO}_{2}$ Demand Controlled Ventilation Technology and Application; Diane Publishing: Darby, PA, USA, 2003; p. 43.

68. Ramalho, O.; Wyart, G.; Mandin, C.; Blondeau, P.; Cabanes, P.-A.; Leclerc, N.; Mullot, J.-U.; Boulanger, G.; Redaelli, M. Association of carbon dioxide with indoor air pollutants andexceedance of health guideline values. Build. Environ. 2015, 93, 115-124. [CrossRef]

69. ANSI/ASHRAE Standard 62.1-2013. Ventilation for Acceptable Indoor Air Quality; American Society of Heating, Refrigerating and Air-Conditioning Engineers, Inc.: Atlanta, GA, USA, 2013.

70. Azuma, K.; Kagi, N.; Yanagi, U.; Osawa, H. Effects of low-level inhalation exposure to carbon dioxide in indoorenvironments: A short review on human health and psychomotorperformance. Environ. Int. 2018, 121, 51-56. [CrossRef]

71. Komarnicki, G.J.K. Lead and cadmium in indoor air and the urban environment. Environ. Pollut. 2005, 136, 47-61. [CrossRef]

72. Al-Rajhi, M.A.; Seaward, M.R.D.; Al-Aamer, A.S. Metal levels in indoor and outdoor dust in riyadh, saudi arabia. Environ. Int. 1996, 22, 315-324. [CrossRef]

73. Kang, Y.; Cheung, K.C.; Wong, M.H. Mutagenicity, genotoxicity and carcinogenic risk assessment of indoor dust from three major cities around the pearl river delta. Environ. Int. 2011, 37, 637-643. [CrossRef]

74. Tan, S.Y.; Praveena, S.M.; Abidin, E.Z.; Cheema, M.S. A review of heavy metals in indoor dust and its human health-risk implications. Rev. Environ. Health 2016, 31, 447-456. [CrossRef]

75. Sanborn, M.D.; Abelsohn, A.; Campbell, M.; Weir, E. Identifying and managing adverse environmental health effects: 3. Lead exposure. Can. Med. Assoc. J. 2002, 166, 1287-1292.

76. Tchounwou, P.B.; Patlolla, A.K.; Centeno, J.A. Carcinogenic and systemic health effects associated with arsenic exposure-A critical review. Toxicol. Pathol. 2003, 31, 575-588. [CrossRef]

77. Faiz, Y.; Tufail, M.; Javed, M.T.; Chaudhry, M.M.; Naila, S. Road dust pollution of cd, cu, ni, pb and zn along islamabad expressway, pakistan. Microchem. J. 2009, 92, 186-192. [CrossRef]

78. Turner, A.; Hefzi, B. Levels and bioaccessibilities of metals in dusts from an arid environment. Water Air Soil Pollut. 2009, 210, 483-491. [CrossRef]

79. Morawska, L.; Afshari, A.; Bae, G.N.; Buonanno, G.; Chao, C.Y.H.; Hänninen, O.; Hofmann, W.; Isaxon, C.; Jayaratne, E.R.; Pasanen, P.; et al. Indoor aerosols: From personal exposure to risk assessment. Indoor Air 2013, 23, 462-487. [CrossRef] [PubMed] 
80. Komae, S.; Sekiguchi, K.; Suzuki, M.; Nakayama, R.; Namiki, N.; Kagi, N. Secondary organic aerosol formation from p-dichlorobenzene under indoor environmental conditions. Build. Environ. 2020, 174, 106758. [CrossRef]

81. Liang, C.-S.; Duan, F.-K.; He, K.-B.; Ma, Y.-L. Review on recent progress in observations, source identifications andcountermeasures of pm2.5. Environ. Int. 2016, 86, 150-170. [CrossRef]

82. Shiraiwa, M.; Ueda, K.; Pozzer, A.; Lammel, G.; Kampf, C.J.; Fushimi, A.; Enami, S.; Arangio, A.M.; Frohlich-Nowoisky, J.; Fujitani, Y.; et al. Aerosol health effects from molecular to global scales. Environ. Sci. Technol. 2017, 51, 13545-13567. [CrossRef]

83. Seinfeld, J.H.; Pandis, S.N. Atmospheric Chemistry and Physics: From Air Pollution to Climate Change; Wiley: Hoboken, NJ, USA, 2016.

84. Vu, T.V.; Ondracek, J.; Zdímal, V.; Schwarz, J.; Delgado-Saborit, J.M.; Harrison, R.M. Physical properties and lung deposition of particles emitted from five major indoor sources. Air Qual. Atmos. Health 2017, 10, 1-14. [CrossRef]

85. Nazaroff, W.W. Indoor particle dynamics. Indoor Air 2004, 14, 175-183. [CrossRef]

86. Bruno, R.C. Sources of indoor radon in houses: A review. J. Air Pollut. Control Assoc. 1983, 32, $105-109$. [CrossRef]

87. Stranden, E.; Berteig, L. Radon in dwellings and influencing factors. Health Phys. 1980, 39, 275. [CrossRef]

88. Gesell, T.F. Background atmospheric radon-222 concentrations outdoors and indoors: A review. Health Phys. 1983, 45, 289-302. [CrossRef] [PubMed]

89. USEPA. Epa Assessment of Risks From Radon in Homes; United States Environmental Protection Agency: Washington, DC, USA, 2003.

90. WHO. Who Handbook on Indoor Radon: A Public Health Perspective; World Health Organization: Geneva, Switzerland, 2009.

91. Unger, A.; Schniewind, A.; Unger, W. Conservation of Wood Artifacts; Sringer: Berlin, Germany, 2001.

92. Holt, E.; Audy, O.; Booij, P.; Melymuk, L.; Prokes, R.; Klánová, J. Organochlorine pesticides in the indoor air of a theatre and museum inthe czech republic: Inhalation exposure and cancer risk. Sci. Total Environ. 2017, 609, 598-606. [CrossRef] [PubMed]

93. USEPA. Pesticides' Impact on Indoor Air Quality. Available online: https://www.epa.gov/indoor-air-qualityiaq/pesticides-impact-indoor-air-quality (accessed on 28 January 2020).

94. Gallart-Mateu, D.; Armenta, S.; Guardia, M.d.1. Indoor and outdoor determination of pesticides in air by ion mobilityspectrometry. Talanta 2016, 161, 632-639. [CrossRef] [PubMed]

95. Colt, J.S.; Severson, R.K.; Lubin, J.; Rothman, N.; Camann, D.; Davis, S.; Cerhan, J.R.; Cozen, W.; Hartge, P. Organochlorines in carpet dust and non-hodgkin lymphoma. Epidemiology 2005, 16, 516-525. [CrossRef] [PubMed]

96. Abb, M.; Breuer, J.V.; Zeitz, C.; Lorenz, W. Analysis of pesticides and pcbs in waste wood and house dust. Chemosphere 2010, 81, 488-493. [CrossRef]

97. Colt, J.S.; Lubin, J.; Camann, D.; Davis, S.; Cerhan, J.; Severson, R.K.; Cozen, W.; Hartge, P. Comparison of pesticide levels in carpet dust and self-reported pest treatment practices in four us sites. J. Expo. Anal. Environ. Epidemiol. 2004, 14, 74-83. [CrossRef] [PubMed]

98. Hwang, H.-M.; Park, E.-K.; Young, T.M.; Hammock, B.D. Occurrence of endocrine-disrupting chemicals in indoor dust. Sci. Total Environ. 2008, 404, 26-35. [CrossRef]

99. Kim, K.-H.; Kabir, E.; Jahan, S.A. Exposure to pesticides and the associated human health effects. Sci. Total Environ. 2017, 575, 525-535. [CrossRef] [PubMed]

100. WHO. Indoor Air Quality: Biological Contaminants: Report on a Who Meeting, Rautavaara; World Health Organization Regional Office for Europe: Copenhagen, Denmark, 1988; Volume 31.

101. Bousquet, J.; Khaltaev, N.; Cruz, A.A.; Denburg, J.; Fokkens, W.J.; Togias, A.; Zuberbier, T.; Baena-Cagnani, C.E.; Canonica, G.W.; Weel, C.V.; et al. Allergic rhinitis and its impact on asthma (aria) 2008. Allergy 2008, 63, 8-160. [CrossRef] [PubMed]

102. Hulin, M.; Simoni, M.; Viegi, G.; Annesi-Maesano, I. Respiratory health and indoor air pollutants based on quantitative exposure assessments. Eur. Respir. J. 2012, 40, 1033-1045. [CrossRef] [PubMed]

103. Baldacci, S.; Maio, S.; Cerrai, S.; Sarno, G.; Barz, N.; Simoni, M.; Annesi-Maesano, I.; Viegi, G. Allergy and asthma: Effects of the exposureto particulate matter and biological allergens. Respir. Med. 2015, 109, 1089-1104. [CrossRef] [PubMed] 
104. Hospodsky, D.; Qian, J.; Nazaroff, W.W.; Yamamoto, N.; Bibby, K.; Rismani-Yazdi, H.; Peccia, J. Human occupancy as a source of indoor airborne bacteria. PLoS ONE 2012, 7, e34867. [CrossRef] [PubMed]

105. USEPA. Carbon Monoxide's Impact on Indoor Air Quality. Available online: https://www.epa.gov/indoorair-quality-iaq/carbon-monoxides-impact-indoor-air-quality (accessed on 28 January 2020).

106. Rashed, M.N. Total and extractable heavy metals in indoor, outdoor and street dust from aswan city, Egypt. Clean 2008, 36, 850-857. [CrossRef]

107. Madany, I.M. The correlations between heavy metals in residential indoor dust and outdoor street dust in bahrain. Environ. Int. 1994, 20, 483-492. [CrossRef]

108. Oh, H.-J.; Jeong, N.-N.; Sohn, J.-R.; Kim, J. Personal exposure to indoor aerosols as actual concern: Perceived indoorand outdoor air quality, and health performances. Build. Environ. 2019, 165, 106403. [CrossRef]

109. Kulmala, M.; Asmi, A.; Pirjola, L. Indoor air aerosol model: The effect of outdoor air, filtration and ventilation on indoor concentrations. Atmos. Environ. 1999, 33, 2133-2144. [CrossRef]

110. Avgelis, A.; Papadopoulos, A.M. Indoor air quality guidelines and standards-A state of the art review. Int. J. Vent. 2004, 3, 267-278. [CrossRef]

111. WHO. Air Quality Guidelines for Europe, 2nd ed.; The World Health Organization: Geneva, Switzerland, 2000.

112. Al-Hemoud, A.; Al-Awadi, L.; Al-Khayat, A.; Behbehani, W. Streamlining IAQ guidelines and investigating the effect of door opening/closing on concentrations of VOCs, formaldehyde, and $\mathrm{NO}_{2}$ in office buildings. Build. Environ. 2018, 137, 127-137. [CrossRef]

113. Abdul-Wahab, S.A.; En, S.C.F.; Elkamel, A.; Ahmadi, L.; Yetilmezsoy, K. A review of standards and guidelines set by international bodies for the parameters of indoor air quality. Atmos. Pollut. Res. 2015, 6, 751-767. [CrossRef]

114. Mandin, C.; Bonvallot, N.; Kirchner, S.; Keirsbulck, M.; Alary, R.; Cabanes, P.A.; Dor, F.; Moullec, Y.L.; Mullot, J.-U.; Peel, A.E.; et al. Development of french indoor air quality guidelines. Clean Soil Air Water 2009, 37, 494-499. [CrossRef]

115. Becher, R.; Hongslo, J.K.; Dybing, E. Guidelines for indoor air in norway-a practicalapproach. Pollut. Atmos. 2000, 166, 245-246.

116. Husman, T.M. The health protection act, national guidelines for indoor air quality and development of the national indoor air programs in finland. Environ. Health Perspect. 1999, 107, 515-517. [CrossRef] [PubMed]

117. Young, C.J.; Zhou, S.; Siegel, J.A.; Kahan, T.F. Illuminating the dark side of indoor oxidants. Environ. Sci. Process. Impacts 2019, 21, 1229. [CrossRef] [PubMed]

118. Gligorovski, S.; Weschler, C.J. The oxidative capacity of indoor atmospheres. Environ. Sci. Technol. 2013, 47, 13905-13906. [CrossRef] [PubMed]

119. Finlayson-Pitts, B.J.; Pitts, J.N. Tropospheric air pollution: Ozone, airborne toxics, polycyclic aromatic hydrocarbons, and particles. Science 1997, 276, 1045-1052. [CrossRef] [PubMed]

120. Alvarez, E.G.; Afif, D.A.; Gligorovski, S.; Schoemaecker, C.; Fittschen, C.; Doussin, J.-F.; Wortham, H. Unexpectedly high indoor hydroxyl radical concentrations associated with nitrous acid. Proc. Natl. Acad. Sci. USA 2013, 110, 13294-13299. [CrossRef]

121. Salthammer, T.; Mentese, S.; Marutsky, R. Formaldehyde in the indoor environment. Chem. Rev. 2010, 110, 2536-2572. [CrossRef]

122. Hult, E.; Willem, H.; Price, P.N.; Hotchi, T.; Russell, M.; Singer, B.C. Formaldehyde and acetaldehyde exposure mitigation in us residences: In-home measurements of ventilation control and source control. Indoor Air 2015, 25, 523-535. [CrossRef]

123. Destaillats, H.; Maddalena, R.L.; Singer, B.C.; Hodgson, A.T.; McKone, T.E. Indoor pollutants emitted by office equipment: A review of reported data and information needs. Atmos. Environ. 2008, 42, 1371-1388. [CrossRef]

124. Stonner, C.; Edtbauer, A.; Williams, J. Real-world volatile organic compound emission rates from seated adults and children for use in indoor air studies. Indoor Air 2018, 28, 164-172. [CrossRef]

125. Misztal, P.K.; Lymperopoulou, D.S.; Adams, R.I.; Scott, R.A.; Lindow, S.E.; Bruns, T.; Taylor, J.W.; Uehling, J.; Bonito, G.; Vilgalys, R. Emission factors of microbial volatile organic compounds from environmental bacteria and fungi. Environ. Sci. Technol. 2018, 52, 8272-8282. [CrossRef]

126. Marmot, A.F.; Eley, J.; Stafford, M.; Stansfeld, S.A.; Warwick, E.; Marmot, M.G. Building health: An epidemiological study of "sick building syndrome" in the whitehall ii study. Occup. Environ. Med. 2006, 63, 283-289. [CrossRef] [PubMed] 
127. Joshi, S.M. The sick building syndrome. Indian J. Occup. Environ. Med. 2008, 12, 61-64. [CrossRef] [PubMed]

128. Redlich, C.A.; Sparer, J.; Cullen, M.R. Sick-building syndrome. Lancet 1997, 349, 1013-1016. [CrossRef]

129. Guo, P.; Yokoyama, K.; Piao, F.; Sakai, K.; Khalequzzaman, M.; Kamijima, M.; Nakajima, T.; Kitamura, F. Sick building syndrome by indoor air pollution in dalian, China. Int. J. Environ. Res. Public Health 2013, 10, 1489-1504. [CrossRef] [PubMed]

130. Kreiss, K. The epidemiology of building-related complaints and illness. Occup. Med. 1989, 4, 575-592.

131. USEPA. Sick Building Syndrome; United States Environmental Protection Agency: Washington, DC, USA, 1991; Volume 4.

132. International Labour Organisation (ILO). Encyclopedia of Accupational Safety and Health-Sick Building Syndrome; International Labour Organisation (ILO): Geneva, Switzerland, 2011.

133. Zhang, X.; Li, F.; Zhang, L.; Zhao, Z.; Norback, D. A longitudinal study of sick building syndrome (SBS) among pupils in relation to $\mathrm{SO}_{2}, \mathrm{NO}_{2}, \mathrm{O}_{3}$ and PM10 in schools in china. PLoS ONE 2014, 9, e112933. [CrossRef]

134. Li, L.; Adamkiewicz, G.; Zhang, Y.; Spengler, J.D.; Qu, F.; Sundell, J. Effect of traffic exposure on sick building syndrome symptoms among parents/ grandparents of preschool children in beijing, China. PLoS ONE 2015, 10, e0128767. [CrossRef]

135. Seltzer, J.M. Building-related illnesses. J. Allergy Clin. Immunol. 1994, 94, 351-361. [CrossRef]

136. Gerardi, D.A. Building-related illness. Clin. Pulm. Med. 2010, 17, 276-281. [CrossRef]

137. Simkovich, S.M.; Goodman, D.; Roa, C.; Crocker, M.E.; Gianella, G.E.; Kirenga, B.J.; Wise, R.A.; Checkley, W. The health and social implications of household air pollution and respiratory diseases. NPJ Prim. Care Respir. Med. 2019, 29, 12. [CrossRef] [PubMed]

138. Grief, S.N. Upper respiratory infections. Prim. Care 2013, 40, 757-770. [CrossRef] [PubMed]

139. Jary, H.; Simpson, H.; Havens, D.; Manda, G.; Pope, D.; Bruce, N.; Mortimer, K. Household air pollution and acute lower respiratory infections in adults: A systematic review. PLoS ONE 2016, 11, e0167656. [CrossRef] [PubMed]

140. Kim, D.; Chen, Z.; Zhou, L.-F.; Huang, S.-X. Air pollutants and early origins of respiratory diseases. Chronic Dis. Transl. Med. 2018, 4, 75-94. [CrossRef]

141. Kim, K.-H.; Jahan, S.A.; Kabir, E. A review of diseases associated with household air pollution due to the use o fbiomass fuels. J. Hazard. Mater. 2011, 192, 425-431. [CrossRef] [PubMed]

142. Smith, K.R.; Samet, J.M.; Romieu, I.; Bruce, N. Indoor air pollution in developing countries and acute lower respiratory infections in children. Thorax 2000, 55, 518-532. [CrossRef] [PubMed]

143. Raaschou-Nielsen, O.; Beelen, R.; Wang, M.; Hoek, G.; Andersen, Z.J.; Hoffmann, B.; Stafoggia, M.; Samoli, E.; Weinmayr, G.; Dimakopoulou, K.; et al. Particulate matter air pollution components and risk for lung cancer. Environ. Int. 2016, 87, 66-73. [CrossRef]

144. Kirkby, J.; Bountziouka, V.; Lum, S.; Wade, A.; Stocks, J. Natural variability of lung function in young healthy school children. Eur. Respir. J. 2016, 48, 411-419. [CrossRef]

145. Smith-Sivertsen, T.; Dı’az, E.; Pope, D.; Lie, R.T.; Dı’az, A.; McCracken, J.; Bakke, P.; Arana, B.; Smith, K.R.; Bruce, N. Effect of reducing indoor air pollution on women's respiratory symptoms and lung function: The respire randomized trial, guatemala. Am. J. Epidemiol. 2009, 170, 211-220. [CrossRef]

146. Regalado, J.; Pe'rez-Padilla, R.; Sansores, R.1.; Ramirez, J.I.P.r.; Brauer, M.; Pare', P.; Vedal, S. The effect of biomass burning on respiratory symptoms and lung function in rural mexican women. Am. J. Respir. Crit. Care Med. 2006, 174, 901-905. [CrossRef]

147. Ceylan, E.; Kocyigit, A.; Gencer, M.; Aksoy, N.; Selek, S. Increased DNA damage in patients with chronic obstructive pulmonary disease who had oncesmoked or been exposed to biomass. Respir. Med. 2006, 100, 1270-1276. [CrossRef]

148. Kim, Y.-K.; Oh, S.-Y.; Jeon, S.G.; Park, H.-W.; Lee, S.-Y.; Chun, E.-Y.; Bang, B.; Lee, H.-S.; Oh, M.-H.; Kim, Y.-S.; et al. Airway exposure levels of lipopolysaccharide determine type 1 versus type 2 experimental asthma. J. Allergy Clin. Immunol. 2007, 178, 5375-5382. [CrossRef] [PubMed]

149. Yang, J.; Kim, E.K.; Park, H.J.; McDowell, A.; Kim, Y.-K. The impact of bacteria-derived ultrafine dust particles on pulmonary diseases. Exp. Mol. Med. 2020, 52, 338-347. [CrossRef] [PubMed]

150. Charpin, D.; Birnbaum, J.; Haddi, E.; Genard, G.; Lanteaume, A.; Toumi, M.; Faraj, F.; Brempt, X.V.D.; Vervloet, D. Altitude and allergy to house-dust mites. A paradigm of the influence of environmental exposure on allergic sensitization. Am. Rev. Respir. Dis. 1991, 143, 983-986. [CrossRef] [PubMed] 
151. Kurmi, O.P.; Lam, K.B.H.; Ayres, J.G. Indoor air pollution and the lung in low- and medium-income countries. Eur. Respir. J. 2012, 40, 239-254. [CrossRef] [PubMed]

152. Torres-Duque, C.; Maldonado, D.; Pe'rez-Padilla, R.; Ezzati, M.; Viegi, G. Biomass fuels and respiratory diseases-A review of the evidence. Proc. Am. Thorac. Soc. 2008, 5, 577-590. [CrossRef] [PubMed]

153. Jiang, X.-Q.; Mei, X.-D.; Feng, D. Air pollution and chronic airway diseases: What should people know and do? J. Thorac. Dis. 2016, 8, E31-E40.

154. Kurmi, O.P.; Arya, P.H.; Lam, K.-B.H.; Sorahan, T.; Ayres, J.G. Lung cancer risk and solid fuel smoke exposure: A systematic review and meta-analysis. Eur. Respir. J. 2012, 40, 1228-1237. [CrossRef]

155. Sun, S.; Schiller, J.H.; Gazdar, A.F. Lung cancer in never smokers-a different disease. Nat. Rev. Cancer 2007, 7, 778-790. [CrossRef]

156. Mu, L.; Liu, L.; Niu, R.; Zhao, B.; Shi, J.; Li, Y.; Scheider, W.; Su, J.; Chang, S.-C.; Yu, S.; et al. Indoor air pollution and risk of lung cancer among chinese female non-smokers. Cancer Causes Control. 2013, 24, 439-450. [CrossRef]

157. Zhang, J.; Smith, K.R.; Ma, Y.; Ye, S.; Jiang, F.; Qi, W.; Liu, P.; Khalil, M.A.K.; Rasmussen, R.A.; Thorneloe, S.A. Greenhouse gases and other airborne pollutantsfrom household stoves in china: A databasefor emission factors. Atmos. Environ. 2000, 34, 4537-4549. [CrossRef]

158. Turner, M.C.; Krewski, D.; Pope, C.A.; Chen, Y.; Gapstur, S.M.; Thun, M.J. Long-term ambient fine particulate matter air pollution and lung cancer in a large cohort of never-smokers. Am. J. Respir. Crit. Care Med. 2011, 184, 1374-1381. [CrossRef] [PubMed]

159. Uzoigwe, J.C.; Prum, T.; Bresnahan, E.; Garelnabi, M. The emerging role of outdoor and indoor air pollution in cardiovascular disease. N. Am. J. Med. Sci. 2013, 5, 445-453. [PubMed]

160. Peters, A.; Liu, E.; Verrier, R.; Schwartz, J.; Gold, D.; Mittleman, M.; Baliff, J.; Oh, J.; Allen, G.; Monahan, K.; et al. Air pollution and incidence of cardiac arrhythmia. Epidemiology 2000, 11, 11-17. [CrossRef] [PubMed]

161. Singh, A.; Kesavachandran, C.N.; Kamal, R.; Bihari, V.; Ansari, A.; Azeez, P.A.; Saxena, P.N.; KS, A.K.; Khan, A.H. Indoor air pollution and its association with poor lung function, microalbuminuria and variations in blood pressure among kitchen workers in india: A cross-sectional study. Environ. Health 2017, 16, 33. [CrossRef]

162. Kampfrath, T.; Maiseyeu, A.; Ying, Z.; Shah, Z.; Deiuliis, J.A.; Xu, X.; Kherada, N.; Brook, R.D.; Reddy, K.M.; Padture, N.P.; et al. Chronic fine particulate matter exposure induces systemic vascular dysfunction via NADPH oxidase and TLR4 pathways. Circ. Res. 2011, 108, 716-726. [CrossRef]

163. Pan, C.-H.; Chan, C.-C.; Wu, K.-Y. Effects on chinese restaurant workers of exposure to cooking oil fumes: A cautionary note on urinary 8-hydroxy-2'-deoxyguanosine. Cancer Epidemiol. Biomark. Prev. 2008, 17, 3351-3357. [CrossRef]

164. Bag, A.; Lee, N.-E. Gas sensing with heterostructures based on twodimensional nanostructured materials: A review. J. Mater. Chem. C 2019, 7, 13367. [CrossRef]

165. Koziej, D.; Lauria, A.; Niederberger, M. Metal oxide particles in materials science: Addressing all length scales. Adv. Mater. 2014, 26, 235-257. [CrossRef]

166. Liu, H.; Li, M.; Voznyy, O.; Hu, L.; Fu, Q.; Zhou, D.; Xia, Z.; Sargent, E.H.; Tang, J. Physically flexible, rapid-response gas sensor based on colloidal quantum dot solids. Adv. Mater. 2014, 26, 2718-2724. [CrossRef]

167. Jariwala, D.; Marks, T.J.; Hersam, M.C. Mixed-dimensional van der waals heterostructures. Nat. Mater. 2017, 16, 170-181. [CrossRef] [PubMed]

168. Choi, H.K.; Park, J.; Myoung, N.; Kim, H.-J.; Choi, J.S.; Choi, Y.K.; Hwang, C.-Y.; Kim, J.T.; Park, S.; Yi, Y.; et al. Gas molecule sensing of van der waals tunnel field effect transistors. Nanoscale 2017, 9, 18644-18650. [CrossRef] [PubMed]

169. Cho, B.; Yoon, J.; Lim, S.K.; Kim, A.R.; Kim, D.-H.; Park, S.-G.; Kwon, J.-D.; Lee, Y.-J.; Lee, K.-H.; Lee, B.H.; et al. Chemical sensing of 2d graphene/mos2 heterostructure device. ACS Appl. Mater. Interfaces 2015, 7, 16775-16780. [CrossRef] [PubMed]

170. Masson, N.; Piedrahita, R.; Hannigan, M. Approach for quantification of metal oxide type semiconductor gassensors used for ambient air quality monitoring. Sens. Actuat. B Chem. 2015, 208, 339-345. [CrossRef]

171. Kim, B.-Y.; Ahn, J.H.; Yoon, J.-W.; Lee, C.-S.; Kang, Y.C.; Abdel-Hady, F.; Wazzan, A.A.; Lee, J.-H. Highly selective xylene sensor based on nio/nimoo 4 nanocomposite hierarchical spheres for indoor air monitoring. ACS Appl. Mater. Interfaces 2016, 8, 34603-34611. [CrossRef] [PubMed] 
172. Baron, R.; Saffell, J. Amperometric gas sensors as a low cost emerging technology platform for air quality monitoring applications: A review. ACS Sens. 2017, 2, 1553-1566. [CrossRef] [PubMed]

173. Oosthuizen, D.N.; Motaung, D.E.; Swart, H.C. Selective detection of co at room temperature with cuo nanoplateletssensor for indoor air quality monitoring manifested by crystallinity. Appl. Surf. Sci. 2019, 466, 545-553. [CrossRef]

174. Saini, J.; Dutta, M.; Marques, G. A comprehensive review on indoor air quality monitoring systems for enhanced public health. Sustain. Environ. Res. 2020, 30, 6. [CrossRef]

175. Pitarma, R.; Marques, G.; Caetano, F. Monitoring Indoor Air Quality to Improve Occupational Health; Springer: Basel, Switzerland, 2016.

176. Persaud, K.; Dodd, G. Analysis of discrimination mechanisms in the mammalian olfactory system using a model nose. Nature 1982, 299, 352-355. [CrossRef]

177. Freund, M.S.; Lewis, N.S. A chemically diverse conducting polymer-based "electronic nose". Proc. Natl. Acad. Sci. USA 1995, 92, 2652-2656. [CrossRef]

178. Scott, S.M.; James, D.; Ali, Z. Data analysis for electronic nose systems. Microchim Acta 2007, 156, $183-207$. [CrossRef]

179. Chen, K.; Gao, W.; Emaminejad, S.; Kiriya, D.; Ota, H.; Nyein, H.Y.Y.; Takei, K.; Javey, A. Printed carbon nanotube electronics and sensor systems. Adv. Mater. 2016, 28, 4397-4414. [CrossRef] [PubMed]

180. Tastan, M.; Gökozan, H. Real-time monitoring of indoor air quality with internet of things-based e-nose. Appl. Sci. 2019, 9, 3435. [CrossRef]

181. Chen, J.; Chen, Z.; Boussaid, F.; Zhang, D.; Pan, X.; Zhao, H.; Bermak, A.; Tsui, C.-Y.; Wang, X.; Fan, Z. Ultra-low-power smart electronic nose system based on three-dimensional tin oxide nanotube arrays. ACS Nano 2018, 12, 6079-6088. [CrossRef] [PubMed]

182. Benammar, M.; Abdaoui, A.; Ahmad, S.H.M.; Touati, F.; Kadri, A. A modular iot platform for real-time indoor air quality monitoring. Sensors 2018, 18, 581. [CrossRef] [PubMed]

183. Chiesa, G.; Cesari, S.; Garcia, M.; Issa, M.; Li, S. Multisensor iot platform for optimising iaq levels in buildings through a smart ventilation system. Sustainability 2019, 11, 5777. [CrossRef]

184. Jo, J.; Jo, B.; Kim, J.; Kim, S.; Han, W. Development of an iot-based indoor air quality monitoring platform. J. Sens. 2020, 2020, 8749764. [CrossRef]

185. Sun, Z.; Wang, S.; Ma, Z. In-situ implementation and validation of a co2-based adaptive demand-controlled ventilation strategy in a multi-zone office building. Build. Environ. 2011, 46, 124-133. [CrossRef]

186. Yick, J.; Mukherjee, B.; Ghosal, D. Wireless sensor network survey. Comput. Netw. 2008, 52, $2292-2330$. [CrossRef]

187. Arroyo, P.; Lozano, J.; Suárez, J.I. Evolution of wireless sensor network for air quality measurements. Electronics 2018, 7, 342. [CrossRef]

188. Guglielmo, D.D.; Brienza, S.; Anastasi, G. Ieee 802.15.4e: A survey. Comput. Commun. 2016, 88, 1-24. [CrossRef]

189. Yang, C.-T.; Chen, S.-T.; Den, W.; Wang, Y.-T.; Kristian, E. Implementation of an intelligent indoor environmental monitoring and management system in cloud. Future Gener. Comput. Syst. 2019, 96, 731-749. [CrossRef]

190. Abraham, S.; Li, X. A cost-effective wireless sensor network system for indoor air quality monitoring applications. Proc. Comput. Sci. 2014, 34, 165-171. [CrossRef]

191. Arroyo, P.; Herrero, J.L.; Suárez, J.I.; Lozano, J. Wireless sensor network combined with cloud computing for air quality monitoring. Sensors 2019, 19, 691. [CrossRef] [PubMed]

192. Pitarma, R.; Marques, G.; Ferreira, B.R. Monitoring indoor air quality for enhanced occupational health. J. Med. Syst. 2017, 41, 23. [CrossRef] [PubMed]

193. Huang, Y.; Ho, S.S.H.; Lu, Y.; Niu, R.; Xu, L.; Cao, J.; Lee, S. Removal of indoor volatile organic compounds via photocatalytic oxidation: A short review and prospect. Molecules 2016, 21, 56. [CrossRef] [PubMed]

194. Haghighat, F.; Lee, C.-S.; Pant, B.; Bolourani, G.; Lakdawala, N.; Bastani, A. Evaluation of various activated carbons for air cleaning-Towardsdesign of immune and sustainable buildings. Atmos. Environ. 2008, 42, 8176-8184. [CrossRef]

195. Zhao, P.; Siegel, J.A.; Corsi, R.L. Ozone removal by hvac filters. Atmos. Environ. 2007, 41, 3151-3160. [CrossRef] 
196. Ligotski, R.; Sager, U.; Schneiderwind, U.; Asbach, C.; Schmidt, F. Prediction of voc adsorption performance for estimation of service life ofactivated carbon basedfilter media for indoor air purification. Build. Environ. 2019, 149, 146-156. [CrossRef]

197. Carter, E.M.; Katz, L.E.; Speitel, G.E.; Ramirez, D. Gas-phase formaldehyde adsorption isotherm studies on activated carbon: Correlations of adsorption capacity to surface functional group density. Environ. Sci. Technol. 2011, 45, 6498-6503. [CrossRef]

198. Jung, J.-S.; Kim, J.-G. An indoor air purification technology using a non-thermal plasmareactor with multiple-wire-to-wire type electrodes and afiber airfilter. J. Electrostat. 2017, 86, 12-17. [CrossRef]

199. Francke, K.-P.; Miessner, H.; Rudolph, R. Plasmacatalytic processes for environmental problems. Catal. Today 2000, 59, 411-416. [CrossRef]

200. Sathiamoorthy, G.; Kalyana, S.; Finney, W.C.; Clark, R.J.; Locke, B.R. Chemical reaction kinetics and reactor modeling of nox removal in a pulsed streamer corona discharge reactor. Ind. Eng. Chem. Res. 1999, 38, 1844-1855. [CrossRef]

201. Urashima, K.; Chang, J.-S. Removal of volatile organic compounds from air streams and industrial flue gases by non-thermal plasma technology . IEEE Trans. Dielectr. Electr. Insul. 2000, 7, 602-614. [CrossRef]

202. Bahri, M.; Haghighat, F. Plasma-based indoor air cleaning technologies: The state of the art-review. Clean Soil Air Water 2014, 42, 1667-1680. [CrossRef]

203. Fujishima, A.; Honda, K. Photolysis-decomposition of water at the surface of an irradiated semiconductor. Nature 1972, 238, 37-38. [CrossRef]

204. Weon, S.; He, F.; Choi, W. Status and challenges in photocatalytic nanotechnology for cleaning air polluted with volatile organic compounds: Visible light utilization and catalyst deactivation. Environ. Sci. Nano 2019, 6, 3185-3214. [CrossRef]

205. Park, H.; Kim, H.-i.; Moon, G.-h.; Choi, W. Photoinduced charge transfer processes in solar photocatalysis based on modified tio2. Energy Environ. Sci. 2016, 9, 411-433. [CrossRef]

206. Patil, K.; Laad, M.; Kamble, A.; Laad, S. A consumer-based smart home with indoor air quality monitoring system. IETE J. Res. 2019, 65, 758-770. [CrossRef]

207. Zhou, B.; Li, W.; Chan, K.W.; Cao, Y.; Kuang, Y.; Liu, X.; Wang, X. Smart home energy management systems: Concept, configurations, and scheduling strategies. Renew. Sustain. Energy Rev. 2016, 61, 30-40. [CrossRef]

208. Paetz, A.-G.; Dütschke, E.; Fichtner, W. Smart homes as a means to sustainable energy consumption: A study of consumer perceptions. J. Consum. Policy 2012, 35, 23-41. [CrossRef]

209. Missaoui, R.; Joumaa, H.; Ploix, S.; Bacha, S. Managing energy smart homes according to energy prices: Analysisof a building energy management system. Energy Build. 2014, 71, 155-167. [CrossRef]

210. Schieweck, A.; Uhde, E.; Salthammer, T.; Salthammer, L.C.; Morawska, L.; Mazaheri, M.; Kumar, P. Smart homes and the control of indoor air quality. Renew. Sustain. Energy Rev. 2018, 94, 705-718. [CrossRef]

211. Kumar, P.; Skouloudis, A.N.; Bell, M.; Viana, M.; Carotta, M.C.; Biskos, G.; Morawska, L. Real-time sensors for indoor air monitoring and challenges ahead indeploying them to urban buildings. Sci. Total Environ. 2016, 560-561, 150-159. [CrossRef] [PubMed]

(C) 2020 by the authors. Licensee MDPI, Basel, Switzerland. This article is an open access article distributed under the terms and conditions of the Creative Commons Attribution (CC BY) license (http://creativecommons.org/licenses/by/4.0/). 